ISSN 1999-4915

www.mdpi.com/journal/viruses

Review

\title{
Human T Lymphotropic Virus Type 1 (HTLV-1): Molecular Biology and Oncogenesis
}

\section{Priya Kannian ${ }^{1,2}$ and Patrick L. Green ${ }^{1,2,3,4, *}$}

1 Center for Retrovirus Research, The Ohio State University, Columbus, OH 43210, USA;

E-Mail: priya.kannian@cvm.osu.edu

2 Department of Veterinary Biosciences, The Ohio State University, Columbus, OH 43210, USA

3 Department of Molecular Virology, Immunology, and Medical Genetics, The Ohio State University, Columbus, OH 43210, USA

4 Comprehensive Cancer Center and Solove Research Institute, The Ohio State University, Columbus, OH 43210, USA

* Author to whom correspondence should be addressed; E-Mail: patrick.green@cvm.osu.edu; Tel.: +1 614-688-4899; Fax: +1 614-292-6473.

Received: 7 July 2010; in revised form: 25 August 2010 / Accepted: 15 September 2010 / Published: 24 September 2010

\begin{abstract}
Human T lymphotropic viruses (HTLVs) are complex deltaretroviruses that do not contain a proto-oncogene in their genome, yet are capable of transforming primary $\mathrm{T}$ lymphocytes both in vitro and in vivo. There are four known strains of HTLV including HTLV type 1 (HTLV-1), HTLV-2, HTLV-3 and HTLV-4. HTLV-1 is primarily associated with adult $\mathrm{T}$ cell leukemia (ATL) and HTLV-1-associated myelopathy/tropical spastic paraparesis (HAM/TSP). HTLV-2 is rarely pathogenic and is sporadically associated with neurological disorders. There have been no diseases associated with HTLV-3 or HTLV-4 to date. Due to the difference in the disease manifestation between HTLV-1 and HTLV-2, a clear understanding of their individual pathobiologies and the role of various viral proteins in transformation should provide insights into better prognosis and prevention strategies. In this review, we aim to summarize the data accumulated so far in the transformation and pathogenesis of HTLV-1, focusing on the viral Tax and HBZ and citing appropriate comparisons to HTLV-2.
\end{abstract}

Keywords: HTLV-1; leukemogenesis; cellular transformation; Tax; HBZ 


\section{General Background and Overview}

Human T lymphotropic virus type 1 (HTLV-1) is a complex leukemogenic retrovirus with a single stranded positive sense RNA genome that expresses unique proteins with oncogenic potential. There are four known strains of HTLV, of which HTLV-1 and HTLV-2 are the most prevalent worldwide. HTLV-1 was originally identified in 1980 in a T cell line derived from a patient with cutaneous T cell lymphoma [1] and was also detected in adult $\mathrm{T}$ cell leukemia (ATL) patients [2,3]. Subsequently, HTLV-2 was identified in a cell line derived from a patient with a variant form of hairy $\mathrm{T}$ cell leukemia [4-6]. Since then, HTLV-2 has not been associated with leukemia/lymphoma; nevertheless, it has been associated with a few sporadic cases of neurological disorders [7]. HTLV-1 can infect $\mathrm{T}$ cells, B cells, monocytes, dendritic cells and endothelial cells with equal efficiency; yet, it can transform only primary $\mathrm{T}$ cells $[8-11]$.

HTLV-1 is an enveloped virus that is approximately $100 \mathrm{~nm}$ in diameter. The inner membrane of the virion envelope is lined by the viral matrix protein (MA). This structure encloses the viral capsid (CA), which carries two identical strands of the genomic RNA as well as functional protease (Pro), integrase (IN), and reverse transcriptase (RT) enzymes. A newly synthesized viral particle attaches to the target cell receptor through the viral envelope (Env) and enters via fusion, which is followed by the uncoating of the capsid and the release of its contents into the cell cytoplasm. The viral RNA is reverse transcribed into double stranded DNA by the RT. This double stranded DNA is then transported to the nucleus and becomes integrated into the host chromosome forming the provirus. The provirus contains the promoter and enhancer elements for transcription initiation in the long terminal repeats (LTR); the polyadenylation signal for plus strand transcription is located in the $3^{\prime}$ LTR [1].

HTLV-1 is dependent on cellular factors for the initial rounds of transcription. The complex retroviral genome codes for the structural proteins Gag (capsid, nucleocapsid, matrix), Pro, polymerase (Pol) and Env from unspliced/singly spliced mRNAs [12-14] and regulatory and accessory proteins from alternatively spliced mRNA transcripts (Figure 1). The two regulatory genes tax and rex are encoded by open reading frames (ORF) IV and III, respectively, and share a common doubly spliced transcript. Tax is the transactivator gene, which increases the rate of viral LTR-mediated transcription [15-17] and modulates the transcription of numerous cellular genes involved in cell proliferation and differentiation, cell cycle control and DNA repair [18-23]. Tax has displayed oncogenic potential in several experimental systems [24-28] and is essential for HTLV-1 and HTLV-2-mediated transformation of primary human $\mathrm{T}$ cells [29-31]. Rex acts post-transcriptionally by preferentially binding, stabilizing and selectively exporting intron-containing viral mRNAs from the nucleus to the cytoplasm [32]. The accessory genes, $p 12 / p 8$ encoded by ORF I and p30/p13 encoded by ORF II are dispensable in standard immortalization assays in culture but are essential for initiation of viral infection and the establishment of persistence in animal models [33-36]. p8 is a proteolytic cleavage product of the 12 parent molecule, whereas the p13 polypeptide, comprised of the carboxy terminus of $\mathrm{p} 30$, is expressed from a distinct mRNA. These accessory proteins may also play a role in gene regulation and contribute to the productive infection of quiescent $\mathrm{T}$ lymphocytes in vitro [37-40]. The minus strand of the proviral genome encodes several isoforms (generated from unspliced and spliced mRNAs) of the HTLV-1 basic leucine zipper factor (HBZ) [41]. HBZ interacts with cellular factors JunB, c-Jun, JunD, cAMP response element binding (CREB) and CREB binding protein (CBP)/p300 
to modulate both viral and cellular gene transcription [42-44]. HBZ also plays a crucial role in $\mathrm{T}$ cell proliferation [45-47]. Among all the viral proteins, experimental evidence implicates Tax as the viral oncoprotein, but emerging data suggests a supporting role for HBZ in the oncogenic process.

Figure 1. Structure of the HTLV-1 proviral genome and gene product key functions. The proviral DNA with the LTRs, and the unspliced, singly spliced and doubly spliced mRNA transcripts are shown to scale. The names of the gene transcripts are depicted inside each specific box (protein coding sequence). Solid lines indicate the exons and the dotted lines indicate the introns. Splice donor sites are indicated by open arrows and major splice acceptor sites are indicated by closed arrows. The numbers represent the nucleotide positions relative to the viral RNA. The general key functions for each of the genes at the protein level are listed to the right (see text for detail).

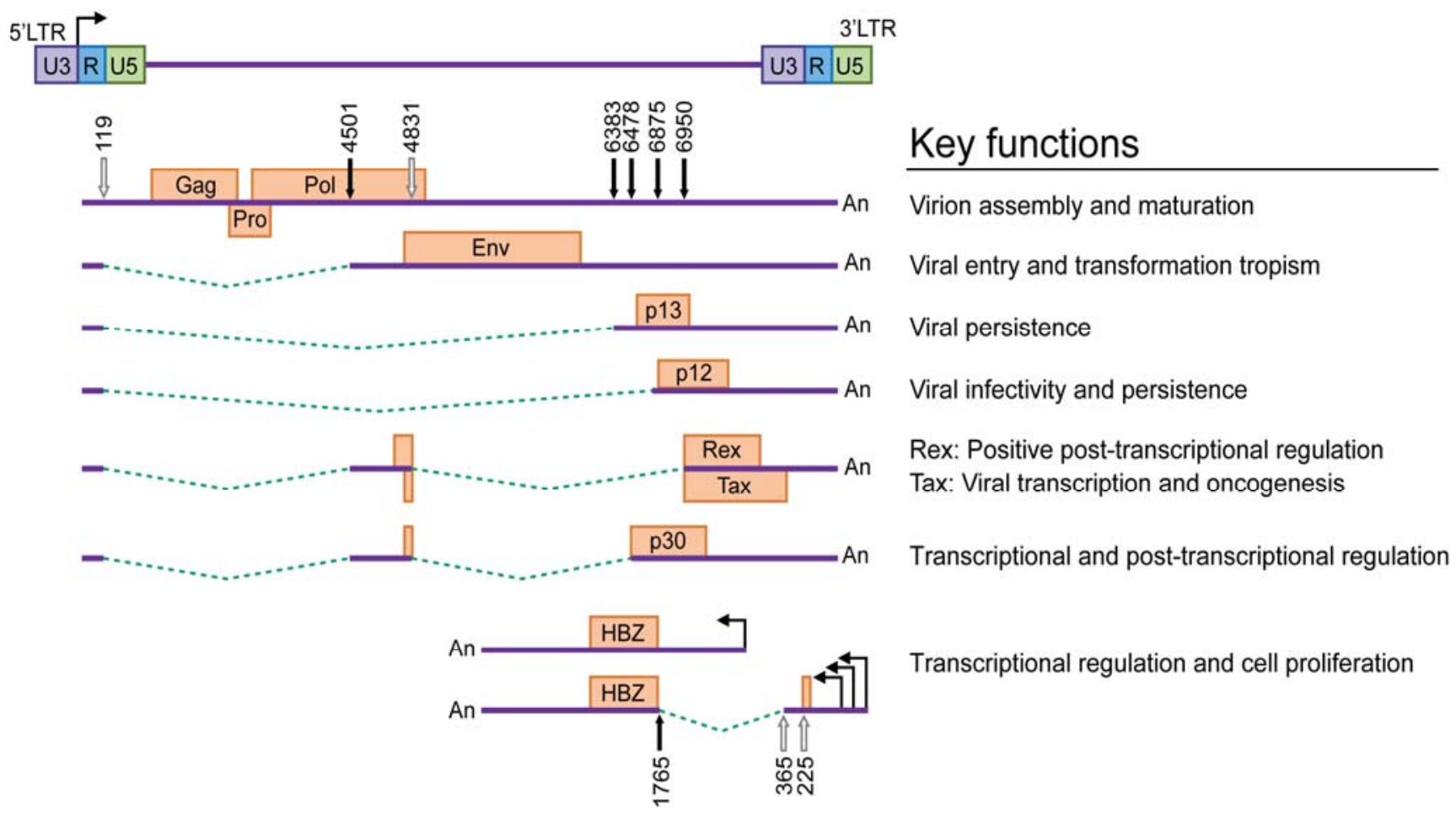

\section{Disease Association}

HTLV-1 predominantly causes ATL and HTLV-1-associated myelopathy/tropical spastic paraparesis (HAM/TSP). There are five different clinical stages of ATL: asymptomatic carrier state, preleukemic state, chronic/smoldering ATL, lymphoma type and acute ATL [48-51]. The majority of the HTLV-1 infected patients are asymptomatic carriers who do not show any clinical symptoms. Even in the absence of symptoms, these individuals are capable of transmitting the virus to others. Approximately $1-2 \%$ of asymptomatic carriers progress to ATL over a $20-40$ year period. HTLV-1 is less commonly associated with other disease conditions such as B cell chronic lymphocytic leukemia [52], chronic inflammatory arthropathy [53-55], HTLV-1 associated uveitis [56,57], T cell nonHodgkin's lymphoma [58,59], T-prolymphocytic leukemia, Sezary's syndrome, small cell carcinoma, 
large granular lymphocytic leukemia (T-gamma lymphoproliferative disease) [60,61], dermatitis, lymphadenitis and Sjogren's syndrome [62].

Although HTLV-2 initially was identified in a $\mathrm{CD}^{+} \mathrm{T}$ cell line derived from a patient with a variant form of hairy cell leukemia [4-6], there have been no subsequent reports of HTLV-2-associated neoplasms. However, there have been sporadic reports of HTLV-2-associated chronic encephalomyelopathy. The clinical symptoms presented are similar to those of HAM/TSP [63]. The prevalence of HTLV-2-associated myelopathy was reported to be $1 \%$ compared to $3.7 \%$ for HAM/TSP [64]. Although other neurological disorders have been reported, their clear association with HTLV-2 is hampered by confounding factors such as intravenous drug use or concomitant HIV infection [63]. To date, HTLV-3 and HTLV-4 have not been associated with any known clinical conditions.

\section{Epidemiology}

Approximately 15-25 million people worldwide are infected with HTLV-1 [62,65]. The virus is endemic in southwestern Japan [66], Africa [67,68], the Caribbean Islands [69] and South America [70] and is frequently found in Melanesia, Papua New Guinea [71], Solomon Islands and Australian aborigines [62]. HTLV-1 also is prevalent in certain populations in the Middle East [72] and India [73,74]. Of HTLV-1 infected patients, only $6.6 \%$ of males and $2.1 \%$ of females develop ATL [62]. HTLV-2 is more prevalent among intravenous drug users (IDUs), and is endemic among IDUs in the USA [75], Europe [76], South America [77] and southeast Asia [78]. HTLV-3 and HTLV-4 have been identified only in African primate hunters [79,80].

\section{Viral transmission}

Of the many possible routes of virus transmission, mother-to-child through breast feeding is the most predominant mode [81]. Transmission rates are 16\% for children born to infected mothers, $27 \%$ for children nursed by infected mothers for more than three months and $5 \%$ for children nursed by infected mothers for less than three months $[82,83]$. Interestingly, about $13 \%$ of bottle-fed children also contract HTLV from their infected mother suggesting a route other than breast-feeding. The infants seroconvert within 1-3 years of age $[83,84]$. Sexual transmission rates are $60 \%$ for male to female, but only $0.4 \%$ for female to male transmission [85-87]. Predisposing factors associated with sexual transmission include the presence of genital ulcers, high viral loads and high antibody titers in the donor [86,87]. Among non-drug using sexual partners of IDUs, sexual transmission is a more common mode then parenteral transmission [88]. Among IDUs, blood and blood products are the most significant source of infection [89]. Approximately $12 \%$ of HTLV infections occur by blood transfusion. Unlike HIV-1, whole cell transfusion is required for transmission of the virus [90,91], with a seroconversion rate of approximately 50\% [90,92]; however, the risk of transmission decreases markedly if the blood units are stored for more than six days before transfusion [91,93]. The development of HAM/TSP has been noted as early as six months after transfusion of an individual with infected blood [94]. In 1988, concerns about transmission of HTLV through blood components led to mandatory blood donor screening for HTLV resulting in a significant decrease in transmission via this mode.

Cell-free infection with HTLV-1 is very inefficient [95]; efficient transmission depends on cell-to- 
cell transfer through direct cell contact, polarization of the microtubule-organizing center (MTOC), which is triggered by Tax, and the formation of a virological synapse, which allows the entry of viral particles, viral proteins and genomic RNA into fresh target cells [96]. As with HIV-1 infection, dendritic cells (DCs) have been demonstrated to play a biphasic role in cell-to-cell transmission of HTLV-1. DCs can capture and transfer the virions to fresh $\mathrm{T}$ cells in a trans fashion or transmit de novo synthesized virions upon infection to fresh T cells in a cis fashion [97].

\section{Viral persistence}

Only about $1 \%$ of asymptomatic carriers progress to ATL, which occurs after about 2-4 decades of clinical latency. On the contrary, for HAM/TSP, disease progression can typically occur within a few years of infection $[94,98]$. In either case, the virus has co-evolved with its host to maintain lifelong persistence with an occasional exacerbation of pathological manifestations. HTLV-1 regulatory and accessory proteins, Rex, p12 and p30/p13 have been implicated to play a role in viral persistence. During the initial stage of infection, translation of Tax is favored over Rex due to a stronger Kozak sequence. Thus, the insufficient translation of Rex results in the export of only the doubly or completely spliced viral mRNAs, due to default splicing by the host cell machinery [99]. Eventually, accumulation of sufficient levels of Rex results in the expression of incompletely spliced mRNA in the cytoplasm, leading to the production of structural and enzymatic gene products and assembly of virus particles. Therefore, Rex is considered a positive regulator that controls the switch between early/latent and late/productive infection, which may help the virus avoid immune surveillance [32,99-101]. The expression of an accessory protein, $\mathrm{p} 30$, results in activation of the G2-M cell cycle checkpoint in Jurkat $\mathrm{T}$ cells, which suggests that $\mathrm{p} 30$ is involved in events that would promote early viral spread and $\mathrm{T}$ cell survival [102]. p30 also binds and retains doubly spliced tax/rex mRNA transcripts in the nucleus, thereby repressing viral gene expression and facilitating immune evasion $[38,103]$. Although p30 is dispensable for HTLV-1-mediated cellular transformation in cell culture, inoculation of rabbits with a p30-deficient virus revealed that p30 expression is required early in infection to sustain high viral loads and promote persistence in rabbits [33]. A recent report could not confirm the p30 ablation phenotype in HTLV-1 infected rabbits, but revealed its importance in viral persistence in macaques [36]. Thus, Rex is a positive post-transcriptional regulator, while p30 is a negative post-transcriptional regulator. Both viral proteins are maintained in a feedback loop to promote viral persistence and evasion of the host immune pressure [104].

A second accessory protein, p12, accumulates in the endoplasmic reticulum (ER) and Golgi compartments [105-107]. p12 interacts with interleukin-2 receptor $\beta$ (IL-2R $\beta$ ) and IL-2R $\gamma$ chains leading to activation of the Janus kinase/signal transducer and activator of transcription 5 (Jak/Stat5) signal transduction pathway, and is required for efficient infection of quiescent primary $\mathrm{T}$ cells and syncytium formation [37,108-110]. The mechanisms by which 12 promotes immune evasion include interference with the presentation of major histocompatibility complex I (MHC class I) molecules by inducing the proteasomal degradation of the newly synthesized MHC molecules [107] and recruitment of $\mathrm{p} 8$ (the proteolytic cleavage product of $\mathrm{p} 12$ that facilitates the trafficking of the protein from the ER to the cell surface through the Golgi apparatus) to the virological synapse to down-regulate proximal signaling [40,111-113]. Another in vitro study demonstrated that p12 promoted cell-to-cell spread by 
inducing lymphocyte function-associated antigen 1 (LFA-1) clustering on $\mathrm{T}$ cells via calciumdependent signaling [114]. In vivo animal models have established an essential role for p12 in persistent viral infection [34,36]. Valeri et al. have suggested that the lack of viral persistence of p12-deficient HTLV-1 in macaques is due to the inability of these viruses to efficiently infect DCs [36]. In the context of an infectious molecular clone, a third accessory protein, p13, was demonstrated to be dispensable for HTLV-1 infection and immortalization of primary T cells in culture [115]; whereas rabbits inoculated with a p13-deficient virus failed to induce a significant immune response and establish a persistent infection [116]. p13 mainly localizes in the mitochondria and suppresses tumor growth by interfering with Ras and Myc oncogenes [117,118]. Although p13 expression is not an apoptotic signal by itself, it sensitizes the cell to FasL and C-2 ceramide-induced apoptosis [118,119]. p13 alters the mitochondrial morphology by disrupting the inner membrane potential and calcium ion flux, and binds farnesyl pyrophosphate synthetase, an enzyme involved in post-translational prenylation of Ras [120]. Since Tax and p13 have opposing effects on apoptosis, the virus balances their functions to achieve two different scenarios. The first is to maintain a balance between the expression levels of Tax and p13 in order to regulate cell survival and proliferation of the infected cells leading to viral persistence. The second is to promote a cooperative effect, where p13 initially increases reactive oxygen species (ROS) in the mitochondria, which increases genetic instability or apoptosis in cells. Then, Tax promotes the selective growth and survival of these genetically unstable cells leading to the accumulation of DNA damage and progression towards neoplastic development [121].

\section{Viral Transformation}

Although HTLV-1 and HTLV-2 display differences in pathogenicity, both viruses can transform primary human $\mathrm{T}$ cells in cell culture. The precise mechanism by which these viruses transform $\mathrm{T}$ cells is not fully understood; however, a number of viral proteins have been implicated to play a role in HTLV- induced T cell transformation and pathogenesis. HTLV-1 and HTLV-2 exhibit differences in transformation tropism, where HTLV-1 preferentially transforms $\mathrm{CD} 4{ }^{+} \mathrm{T}$ cells both in vitro and in vivo while HTLV-2 transforms $\mathrm{CD}^{+} \mathrm{T}$ cells in in vitro co-culture assays [122-125]. Tax-mediated transcription of HTLV-1 is significantly increased in $\mathrm{CD} 4^{+} \mathrm{T}$ cells as compared to $\mathrm{CD} 8^{+} \mathrm{T}$ cells, but the viral burden is higher in the latter [126,127]. The in vivo tropism of HTLV-2 appears to be less clear. Although Ijichi et al. have shown that HTLV-2 has a preferential tropism for $\mathrm{CD}^{+} \mathrm{T}$ cells in vivo [128], unlike HTLV-1, both $\mathrm{CD}^{+} \mathrm{T}$ cells and $\mathrm{CD} 8^{+} \mathrm{T}$ cells are equally susceptible to HTLV-2 infection and subsequent viral gene expression, with a greater proviral burden observed in $\mathrm{CD}^{+} \mathrm{T}$ cells $[123,124,129]$. In a quest to find the genetic determinant responsible for this differential transformation tropism, the first HTLV-1/2 recombinant viruses were generated and tested. Unexpectedly, results revealed that neither Tax nor the viral LTR sequences played a role $[125,130]$. Indeed, it was the viral envelope that conferred this distinct transformation tropism [130]. The viral envelope has two glycoproteins, surface component (SU) and transmembrane component (TM). SU binds to the cellular receptor, while TM triggers the fusion of the viral and cellular membranes, facilitating viral entry. Binding studies have supported the role of viral envelope in the distinct transformation tropism by showing that HTLV-1 binds to heparin sulfate proteoglycans (HSPG) on 
$\mathrm{CD}^{+}{ }^{\mathrm{T}}$ cells, while HTLV-2 binds to glucose transporter 1 (GLUT-1) on CD8 ${ }^{+} \mathrm{T}$ cells [131].

The viral transactivator protein, Tax, and the minus strand-encoded HBZ have been shown to play an essential role in HTLV-1 induced oncogenesis. Tax-induced activation of the nuclear factor $\kappa B$ $(\mathrm{NF}-\mathrm{\kappa B})$ pathway [30] and the constitutive activation of the Jak/Stat pathway [132], and HBZ-induced activation or regulation of cellular factors like E2F1, JunB, c-Jun, JunD, CREB and CBP/p300 [112] have been implicated in transformation. The roles of Tax and HBZ in the induction of transformation are discussed in detail below. In addition, the accessory protein, p12, is also a modulator of $\mathrm{T}$ cell proliferation and immune function. p12 interacts with the $16 \mathrm{kDa}$ subunit of the vacuolar ATPase, a complex important for the function of lysosomes and endosomes, and is implicated in transformation pathways [133,134]. Furthermore, p12 augments $\mathrm{Ca}^{2+}$ release from the ER via its ability to bind with calnexin and calreticulin, which regulate storage and release of $\mathrm{Ca}^{2+}$ from the ER, as well as with calcineurin, a calcium/calmodulin-dependent phosphatase, resulting in the activation of Nuclear Factor of Activated T Cells (NFAT). NFAT has a role in integrating calcium signaling with other signaling mechanisms in $\mathrm{T}$ cells [135-138]. Although p12 has been associated with proliferation, studies utilizing an infectious molecular clone indicated that abrogation of p12 message or protein had no effect on viral replication and immortalization of primary $\mathrm{T}$ cells in vitro [115].

\section{Viral pathogenesis}

The pathogenesis of ATL involves four stages: infection, polyclonal proliferation, clinical latency and tumorigenesis. HTLV-1 infects activated and dividing $\mathrm{T}$ cells with greater efficiency than quiescent T cells [139]. Env facilitates binding and entry into target cells. T cells become stimulated, which may be mediated by CD2/LFA-3, LFA-1/intracellular adhesion molecule (ICAM) and IL-2/IL-2R [140]. The activated T cells then form a pool of proliferating lymphoblasts. At this stage, the polyclonal population of cells is not leukemic. Indefinite T cell growth occurs in HTLV-1 infected individuals, but disease onset is seen only in a small percentage of these individuals. Tax and HBZ play a crucial role in the cell alteration process by triggering changes in a variety of intracellular signal transduction pathways, both by up-regulating and down-regulating viral and cellular gene expression in order to initiate neoplastic transformation [141,142]. The subsequent proliferation of the transformed T cells becomes IL-2 independent, which correlates with constitutive activation of the Jak/Stat pathways as well as decreased expression of src homology 2 (SH2)-containing tyrosine phosphatase-1 (SHP-1) protein, which regulates signaling from several hematopoietic surface receptors [143,144]. This transition usually correlates with significantly more rapid disease progression [145]. Upon infection of $\mathrm{T}$ cells, a period of clinical latency is observed in HTLV-1 carriers, which usually lasts 20 to 40 years. During this period, the viral genes are expressed at subdetectable levels to evade immune surveillance. HTLV-1 undergoes epigenetic silencing and also promotes chromosomal aberrations, leading to selection and evolution of monoclonal tumor populations. The degree of cytogenetic aberration is directly proportional to disease severity. The transactivation of proto-oncogenes such as $c$-fos, egr-1 and egr-2 by Tax may also contribute to leukemogenesis [146]. The development of tumors delineates the end of clinical latency and development of ATL in these patients.

Several animal models have been used to study HTLV-1 infection, persistence, and to some extent 
disease progression, although so far, these animal models have not been able to successfully mimic human ATL. To date, rabbits [147,148], rats [149,150], mice and non-human primates have been used as experimental models. Rabbits have been used more extensively because of ease of handling and development of a consistent infection that mimics the asymptomatic infection in humans. Although rabbits provide a good infection model, they are less helpful as tumorigenic models because they do not develop disease [151-155]. Certain strains of rats have been used to study HAM/TSP, although the neurodegenerative lesions are not very similar to those of humans. Results using rat models also suffer from variability depending on the rat strain employed $[149,150]$. Furthermore, in order to study tumorigenesis, the rats need to be immunodeficient [156]. Some non-human primates like Cynomolgus macaques and squirrel monkeys have been tested as animal models. Although these animals seroconvert variably, there are no typical signs of clinical disease [36,157,158]. Even though some investigators may argue that this subclinical state could mimic the human asymptomatic phase, the debate continues as to whether these models will mimic ATL if animals are maintained for longer periods; the long waiting time for such experiments make them unappealing. Lastly are the mouse models, where both xenograft and transgenic models have been utilized. Genetically normal and immunocompetent mice are not efficiently infected with HTLV-1 and they do not develop a natural course of illness. However, histologic analysis of xenograft models has shown ATL cells in various organs depending on the inoculation route. In addition, biochemical characteristics typical to HTLV-1 infection of humans including parathyroid hormone related protein (PTHrP) expression and increased serum IL-2R $\alpha$ and $\beta 2$-microglobulin levels correspond to increasing tumor burden in these mice [159-167]. Transgenic mice provide a good model to test the role of individual HTLV-1 genes in the pathogenesis of ATL. They also help in understanding the underlying relationship between the viral genes and their ability to cause unregulated cell growth [26,168-174]. The biggest caveat in such mouse models is the physiological relevance of these findings in the context of a completely active immune system. Humanized mouse models that are being used more extensively in HIV research thus far have been less attractive for HTLV-1 research because of the prolonged clinical latency period in the latter.

\section{Role of Tax in HTLV-1 induced oncogenesis}

Tax, a transactivator protein, triggers a plethora of events like cell signaling, cell cycle regulation and interference with checkpoint control and inhibition of DNA repair. Tax is expressed from a doubly spliced mRNA transcript. Although Tax shares the same mRNA transcript with Rex, translation of Tax is favored over Rex due to a stronger Kozak sequence. Tax made in the cytoplasm is translocated into the nucleus, where it binds to its response element and activates viral LTR-mediated transcription.

\subsection{Effect of Tax on transcription factors}

The Tax response element (TxRE) in the unique 3' (U3) region of the 5'LTR is a 21-bp triple repeat, which contains an octamer motif TGACG(T/A)(C/G)(T/A) that is flanked by a $\mathrm{G}$ stretch at the 5 'end and a $\mathrm{C}$ stretch at the $3^{\prime}$ end. This octamer motif is homologous to the cAMP response element (CRE) 5'-TGACGTCA-3' [175,176]. Tax does not have the specificity to directly bind TxRE DNA in the 5'LTR. In vitro biochemical studies have shown that Tax interacts with CRE binding/activating 
transcription factors (CREB/ATF) and forms a ternary complex with TxRE [177-183]. All of these proteins share common basic residues that facilitate DNA binding and include a basic leucine zipper domain (bZIP), which allows homo- and heterodimerization, which in turn is responsible for the ternary complex formation [184]. Tax interacts with the bZIP domain of CREB/ATF, enhances its dimerization, increases its affinity to the homologous octamer motif in the viral LTR and finally stabilizes the ternary complex by directly binding to the GC-rich flanking sequences [185-190]. Tax then recruits co-activators like $\mathrm{CBP} / \mathrm{p} 300$ and p300/CBP-associated factor (P-CAF) for the initiation of transcription [191,192]. Tax binds to CREB/ATF and regulates LTR-mediated transactivation both positively and negatively. Tax also binds to co-activators of CREB - transducers of regulated CREB activity (TORCs), which facilitate the binding of Tax to CREB/ATF in a p300 and CBP-dependent manner [193,194]. Through its interactions with CREB/ATF, Tax represses a number of cellular genes including $p 53$, cyclin A and c-myb [19,195,196]. Tax also activates promoters under the control of the serum responsive factor (SRF) responsive element (SRE) motifs via interactions with transcription factors associated with the SRF pathway. The main transcription factor under the transcriptional control of SRF is activator protein 1 (AP-1), which is triggered in response to various stimuli including cytokines, growth factors, stress signals, and oncogenes. AP-1 is either a homo- or heterodimeric complex of Fos (c-Fos, FosB, Fra1 and Fra2) and Jun (c-Jun, JunB and JunD) [146,197]. Moreover, Tax binds directly to SRF and to various members of the ternary complex factor (TCF) such as SRF accessory protein 1 (Sap1), Elk1, spleen focus forming virus (SFFV) proviral integration oncogene 1 (Spi1) and Ets1 [198-203]. These interactions increase the binding of SRF to multiple different SRE sequences located in the Fos/Jun promoters, thus occupying the CArG box $\left(\mathrm{CC}[\mathrm{A} / \mathrm{T}]_{6} \mathrm{GG}\right)$; then the TCF establishes a protein interaction with an upstream Ets box (GGA[A/T]). Once these complexes stabilize, Tax recruits the co-activators $\mathrm{CBP} / \mathrm{p} 300$ and P-CAF to activate transcription [203]. Thus, Tax transactivation from CREB and SRF responsive sites involves its interaction with transcription factors by enhancing DNA binding, altered site selection and co-activator recruitment.

\subsection{Tax and T cell transformation}

Apart from activating viral gene transcription, Tax induces various cellular functions in the HTLV-1 infected cells and thus, renders them susceptible to viral persistence and thereby initiates neoplastic transformation. NF- $\kappa \mathrm{B}$ is a key player in Tax-induced $\mathrm{T}$ cell transformation. The NF- $\kappa \mathrm{B}$ family of transcription factors includes five structurally related members - RelA, RelB, c-Rel, NF- $\kappa B 1$ (p50/p105) and NF-kB2 (p52/p100) [204-206]. The precursor proteins, p105 and p100, are proteolytically cleaved to the mature p50 and p52 forms. These proteins form various dimeric complexes in the cytoplasm. In naïve T cells, the dimers are trapped by inhibitory I $\mathrm{B}$ proteins such as

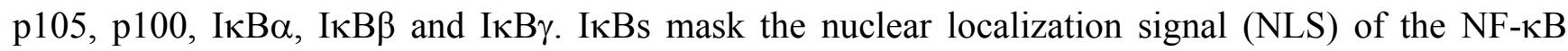
factors by physical interaction [204,205]. Upon activation of the T cells by an appropriate stimulus,

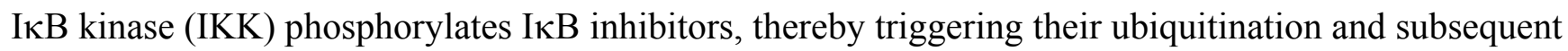
proteasomal degradation. This event leads to the exposure of the NLS and the eventual translocation of the NF- $\kappa \mathrm{B}$ factors to the nucleus, where they transactivate or repress target genes bearing a $\kappa \mathrm{B}$ enhancer [204,205,207]. The NF-kB family plays a crucial role in immune functions such as innate and adaptive responses, survival of lymphocytes and lymphoid tissue development [206]. Therefore, any aberrant NF- $\mathrm{BB}$ activation could lead to the genesis of cancer, especially hematologic 
malignancies such as leukemia, lymphoma and myeloma [208]. NF- $\mathrm{BB}$ functions via two signaling pathways - classical and alternate. Both pathways regulate overlapping but distinct cellular genes. The classical pathway is activated by inflammatory cytokines, genotoxic stress, antigens and toll-like receptor (TLR) stimulation, which results in degradation of $I \kappa B$ inhibitor and the translocation of p50/RelA complex into the nucleus. The alternate pathway is activated by a subset of tumor necrosis factor (TNF) family members such as CD40L, lymphotoxin- $\beta$, B cell activating factor belonging to the TNF family (BAFF), receptor activator for NF- $\mathrm{B}$ ligand (RANKL) and TNF-like weak inducer of apoptosis (TWEAK). Activation of the alternate pathway results in the processing of $\mathrm{p} 100 / \mathrm{RelB}$ into p52/RelB and the translocation of the latter to the nucleus [209].

In naïve $\mathrm{T}$ cells, the activity of NF- $\mathrm{B}$ pathways is tightly controlled. NF- $\kappa \mathrm{B}$ is transiently activated upon immune stimulation, but constitutively activated in HTLV-1 infected T cells [210-213]. Constitutive activation of NF- $\kappa \mathrm{B}$ is mediated by Tax and is essential for the induction of $\mathrm{T}$ cell transformation. Mechanistically, Tax binds to IKK $\gamma(\mathrm{NF}-\kappa \mathrm{B}$ essential modulator, NEMO) and activates the IKK complex [214,215]. Tax also binds to transforming growth factor $-\beta$ activated kinase 1 (TAK1), a mitogen activator protein-3 kinase (MAP3K), and stimulates IKK activity [216]. Tax undergoes post-translational modifications including phosphorylation, acetylation, sumoylation and ubiquitination [217-223]. Of these, ubiquitination is crucial for binding to NEMO and is dependent on E2 ubiquitin-conjugating enzyme, Ubc13 [221]. NEMO-related protein (NRP/Optineurin) binds to Tax and positively modulates the ubiquitination of Tax resulting in activation of the NF- $\kappa B$ pathway [224]. Tax expressed by HTLV-1 activates both the classical and


leading to IKK $\alpha$-mediated p100 phosphorylation and its subsequent cleavage into p52 [225]. HTLV-2 Tax can activate the classical pathway at levels comparable to that of HTLV-1 Tax, but cannot activate the alternate pathway because the former cannot interact with p100 [226]. Dependence on NF-kB activation by Tax for the immortalization of $\mathrm{T}$ cells both in vitro and in vivo has been demonstrated by several groups $[29,30,227]$. Tax-mediated NF- $\kappa \mathrm{B}$ activation stimulates a number of cytokines and their corresponding receptors such as IL-2/IL-2R, IL-9, IL-13, IL-15/IL-15R, IL-21/IL-21R, IL-8, CCL2, CCL5, CCL22, CCR9, CXCR7, CD40, OX40/OX40L and 4-1BB/4-1BBL [228-245]. Approaches to block NFKB using drugs or peptide inhibitors have resulted in tumor cell regression in animal models [227].

\subsection{Tax and pathogenesis}

Tax has two main functions in the pathogenesis of HTLV-1. First is constitutive cell cycle progression and the second is resistance to apoptosis. Tax induces cell cycle progression by proteinprotein interaction and transcriptional regulation of cell cycle-associated proteins. Specifically, Tax stimulates the transition of cells from G1 to S phase through the hyper-phosphorylation of Rb and activation of E2F transcription factors and by the induction of cyclin D2 and cyclin-dependent kinase 6 (CDK6) via the NF- $\kappa$ B pathway (both classical and alternate). In addition, Tax activates CDK4/CDK6 through the direct interaction with CDK4, CDK6 and CDK inhibitors like CDKN1A, p16 ${ }^{\mathrm{INK} 4 \mathrm{~A}}$ and p15 ${ }^{\text {INK4B }}$ [246-255]. Thus, Tax induces the expression of cell cycle regulators in an NF- $\mathrm{B}$-dependent manner and subsequently activates them in an NF- $\kappa \mathrm{B}$-independent manner. Tax also influences 
transformation and regulates apoptosis in T cells by activation of the phosphatidyl inositol 3 kinase (PI3K)/Akt pathway. Mechanistically, Tax frees a catalytic $\mathrm{p} 110 \alpha$ subunit of the PI3K complex from an inhibitory p $85 \alpha$ subunit by binding directly to the latter [256]; Tax induces the RelA-mediated sequestration of p300 from the promoters of phosphatase and tensin homolog (PTEN) and SH2 domain-containing inositol phosphatase - 1 (SHIP-1), thereby down-regulating their expression [257]; Tax influences a number of factors that affect the PI3K/Akt pathway including mammalian target of rapamycin (mTOR), AP-1, NF- $\kappa \mathrm{B}, \mathrm{CREB} / \mathrm{ATF}, \beta$-catenin, and hypoxia inducible factor - 1 (HIF-1) [256,258-261]. Tax induces anti-apoptotic proteins such as Bcl-xL, survivin, cFLIP, xIAP, cIAP1 and

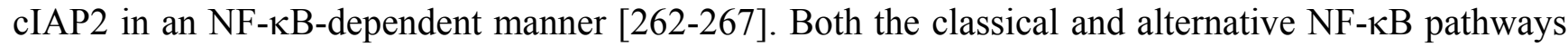
play a positive role in the inhibition of apoptosis in HTLV-1-infected T cells.

Tax exhibits its oncogenic potential by both clastogenic DNA damage and aneuploidic effects $[112,184,268,269]$. Tax promotes clastogenic DNA damage by repressing the expression of DNA polymerase $\beta$, which is involved in base excision repair, nucleotide excision repair, and repression of human telomerase reverse transcriptase (hTERT), thus subverting Ku80 activity (a protein essential for DNA repair) [269]. All of these mechanisms result in reduced protection from double stranded DNA breaks as well as telomere extension, which could be the reason for end-to-end fusion of chromosomes observed in HTLV-1-infected cells. During DNA damage, the complex DNA damage response (DDR) signaling molecules such as ATM, ATR and DNA-PK kinases become activated and orchestrate DNA repair [268,270,271]. Tax can induce checkpoint activation and cell cycle arrest at the G1 phase by inducing p27/kip1 and p21/waf1 [272]. This function of Tax appears to be paradoxical to its transforming activity. Nevertheless, the constitutive activation of the DDR pathway and the checkpoint adaptation facilitating the proliferation of $\mathrm{T}$ cells with DNA damage causes genetic instability and ultimately evolution of ATL clones. Tax causes aneuploidy by interacting with proteins that monitor chromosomal segregation during mitosis through the following mechanisms: induction of supernumerary centrosomes and multipolar mitosis via interactions with Tax-1 binding protein-2 (TAX1BP2) and Ran/TC4-binding protein (RanBP1); unscheduled degradation of securin and cyclin B1 by interacting with CDC20-associated anaphase-promoting complex (APC); and impairment of mitotic spindle assembly checkpoint protein 1 (MAD1) activity, an integral function of the mitotic spindle assembly checkpoint (SAC) [112]. Tax also plays a key role in promoting oncogenesis by abrogating the function of the tumor suppressor gene, $p 53$. The biological activity of p53 is central to the integrity of a cell in that any loss of its function either due to mutation or inactivation increases the chance of genetic instability leading to oncogenesis. The subcellular localization and phosphorylation status of p53 are critical for its function. In a majority of HTLV-1 infected cell lines, p53 function is impaired although the protein itself is sufficiently expressed and stable. Two mechanisms have been identified for the abrogation of p53 function by Tax. First, it was demonstrated that the expression of Tax-1 or Tax-2 impaired the functionally relevant phosphorylation of p53 at serines 15 and 392; Tax activation of the NF- $\kappa$ B pathway was essential for this activity [273,274]. Second, it was demonstrated that Tax competes with $\mathrm{p} 53$ for the binding with $\mathrm{CBP} / \mathrm{p} 300$, which results in the decreased ability of p53 to activate cell cycle control genes [275,276].

A PDZ binding motif (PBM) or domain, which is comprised of a four amino acid sequence at the C-terminus of HTLV-1 Tax, has been implicated in T cell proliferation and transformation. The PDZ domain is named after the first identified PDZ-containing proteins, post-synaptic density protein 
(PSD-95), Drosophila discs large protein (DLG) and epithelial tight junction protein (Zonula Occludens-1). The PDZ domain is commonly used in eukaryotic cells to recruit and organize proteins to sites of cellular signaling. Using both virus gene knockout and knockin approaches, Xie et al. investigated the role of the Tax PBM in both cell culture and infected animals. These authors demonstrated that the PBM of HTLV-1 Tax significantly increased HTLV-1-induced primary T cell proliferation in vitro. Moreover, HTLV-1 proviruses containing a deletion in this four amino acid motif had severely attenuated infectivity and persistence in vivo [277]. HTLV-2 Tax does not contain this PBM domain. Interestingly, a chimeric HTLV-2 virus containing the HTLV-1 Tax PBM significantly increased primary human $\mathrm{T}$ cell proliferation in vitro, thus lending further support that this domain plays a key role in Tax pathogenic activity[277]. The three PDZ-containing proteins in humans are hDLG, membrane associated guanylate kinase (MAGUK) with inverted orientation -3 (MAGI-3) and precursor of interleukin-16 (pro-IL-16), all of which have been implicated in tumor suppression or cell cycle regulation, and have been demonstrated to interact with Tax PBM [278-281]. HTLV-1 Tax PBM competes with the adenomatous polyposis coli (APC) tumor suppressor protein for the hDLG binding domain [282]; PBM competes with another tumor suppressor, phosphatase with tensin homology mutated in multiple advanced cancers (PTEN/MMAC) for binding to MAGI-3 [283]; and PBM also interacts with the first PDZ domain of pro-IL-16 [280], all of which result in the reversal of cell cycle arrest in G0/G1 phase induced by hDLG. Using a panel of Tax-1 and Tax-2 mutants, the PBM has been demonstrated to enhance micronuclei induction in transfected cells, which probably plays a role in the genomic instability caused by Tax [277,284,285]. PBM also has been shown in other oncogenic viruses including human papillomavirus and adenovirus, which points toward a possible mechanism for PBM and PDZ-containing proteins in cellular transformation and pathogenesis by tumorigenic viruses [209,286,287].

\section{Role of HBZ in HTLV-1-induced oncogenesis}

HBZ is encoded by an mRNA transcribed from the minus strand of the proviral genome. Transcription from the antisense strand of HTLV-1 was first reported in 1989 [288]. Almost a decade later, the viral protein HBZ was detected in HTLV-1 transformed cell lines. HBZ was identified as a binding partner of CREB-2 by yeast two-hybrid assays [41]. Hbz transcription is driven by a TATAless promoter in the $3^{\prime}$ end of the proviral genome activated primarily by Sp1 [289]. HBZ is expressed from three mRNA transcripts, unspliced form (usHbz) and two spliced forms $(\mathrm{sHbz})$ - major and minor, as identified by $5^{\prime}$ rapid amplification of cDNA ends (RACE) [46,290,291]. The sHbz transcripts have multiple initiation sites in the unique $5^{\prime}$ (U5) and R regions of the $3^{\prime} \mathrm{LTR}$, whereas the $u s H b z$ initiates from within the tax gene. The TxRE in the 3'LTR functions as the promoter enhancer element for $\mathrm{Hbz}$ transcription, although its function is much weaker compared to the 5'LTR TxRE [289,292]. This provides one explanation why the gene expression of tax and $\mathrm{Hbz}$ are inversely proportional during the course of HTLV-1 infection and disease progression. There are marked differences between the unspliced and spliced HBZ isoforms both at the RNA and protein levels (Table 1). Hbz transcripts are expressed at relatively constant levels in ATL cells, regardless of the tax expression levels [293]. Total $\mathrm{Hbz}$ transcripts detected in an infected individual are directly proportional to the proviral load, probably due to their dependence on Sp1 for transcription [46]. The 
difference between $\mathrm{sHbz}$ and $\mathrm{usHbz}$ transcripts is the presence of the first exon in the former. This region corresponds to a small portion of the Rex-responsive element (RxRE) in the sense strand. In the antisense strand, this region forms a variable stem loop structure that might interact with host factors to induce the proliferation of ATL cells in an IL-2-independent manner [46,289]. Saito et al. have reported a correlation between the $\mathrm{Hbz}$ transcript levels and the severity of HAM/TSP, which suggests a possible role for HBZ in the pathogenesis of HAM/TSP [293].

Table 1. Structural and functional differences between the unspliced and spliced Hbz.

Structure/Function

RNA

Transcription initiation site $[47,293,294]$

Weak promoter enhancement by TxRE $[47,293,294]$

mRNA transcription efficiency

$[47,293,294]$

Promotes T cell proliferation [46,289]

\section{$\underline{\text { Protein }}$}

Half-life of the protein $[47,293,294]$

Detection levels in ATL cell lines and HTLV-1 infected cells

Inhibition of AP-1 transcription [42,45]

Delivery of c-Jun to proteasomal degradation $[42,45]$
usHBZ

sHBZ
Within the tax gene

?

$0.25 \mathrm{X}$

Weak

Short

Low

Weak

Strong
Strong

Multiple sites in the U5 and $\mathrm{R}$ region of the $3^{\prime} \mathrm{LTR}$

Yes

$1 \mathrm{X}$

Long

High

Strong

Weak

Western blot analyses have shown the expression of sHBZ protein in almost all ATL cell lines. The HBZ protein contains three domains - activation, central and basic leucine zipper (bZIP) [41,295]. HBZ binds to cellular factors like c-Jun, JunB, JunD, CREB-2 and CREB via the bZIP domain $[41,42,44]$. The bZIP and the activation domains are involved in the activation of JunD [45], increase of hTERT [296] and the binding with the p65 subunit of NF- $\kappa B$ [297], thereby inhibiting the classical pathway of NF- $\kappa \mathrm{B}$ activation. HBZ protein has been shown to localize in the nucleoli with a speckled staining pattern by immunohistochemistry. The integrity of the amino acid sequence of HBZ must be maintained for this speckled pattern to be observed [295]. This nuclear localization signal is located in the central domain and is comprised of three regions: two regions rich in basic amino acids and one DNA binding domain. HBZ interacts with the CBP/p300 KIX domain and the $26 \mathrm{~S}$ proteasome through the activation domain [298]. HBZ interacts with CREB-2 (ATF-4) through the bZIP domain, which abolishes the binding of CREB-2 to TxRE in the 5'LTR and, in turn, results in the down- 
regulation of Tax-mediated viral transcription in an HBZ dose-dependent manner [41,299]. HBZ inhibits the transcriptional activity of cellular factors by localizing in the heterochromatin and also by sequestering JunB into nuclear bodies [300,301]. HBZ disrupts the basal transcription of both HTLV-1 and cellular promoters by attenuation of AP-1 activation (Fos/Jun dimers) via degradation of c-Jun in a ubiquitination-independent manner and also by directly interacting with the $26 \mathrm{~S}$ proteasome, thereby causing proteasomal degradation of c-Jun $[42,45]$. In addition, HBZ interacts with JunD to activate cellular genes including hTERT, which activates the telomerase in cell mitosis, a critical late event in tumor progression that indicates a role for HBZ in the development and maintenance of leukemic cells [296]. It is interesting to note that JunD is primarily a growth suppressor that functions by interacting with the tumor suppressor, menin [302]. However, in the presence of HBZ, JunD forms homodimers with HBZ and thereby increases its transcriptional and transforming activity. Recently, both isoforms of HBZ have been shown to hetero-dimerize with MafB via their bZIP domains and abrogate the DNA binding activity of MafB. MafB is a transcriptional factor that is responsible for lineage-specific hematopoiesis. Additional investigations are required to delineate the effect of this suppression [303].

\section{HBZ and pathogenesis}

Although no antibody responses against HBZ have been detected so far from HTLV-1-infected carriers [304], recent evidence has shown that HBZ is immunogenic in vitro. When exposed to DCs, HBZ was processed and presented in the context of HLA-A*0201. HBZ peptides induced specific cytotoxic T lymphocytes (CTL), but they failed to lyse HLA-A*0201-positive HTLV-1-infected T cell lines and ATL cells. This could be because the amount of HBZ protein expressed by HTLV-1 infected cells is not sufficient to be recognized by the HBZ-specific CTLs. HBZ-specific CTLs are detected in very sparse numbers in ATL patients and healthy carriers [305].

Kinetic analyses of gene expression levels in HTLV-1 proviral plasmid over-expression studies in cell culture revealed that $\mathrm{Hbz}$ mRNA levels are significantly lower than tax/rex mRNA levels [306]. In the context of an infectious molecular clone, like other accessory gene products, $\mathrm{Hbz}$ was dispensable for immortalization of primary human $\mathrm{T}$ cells in vitro. Stable $\mathrm{T}$ cell clones generated with $\mathrm{Hbz}$ defective proviruses produced significantly higher levels of p19 Gag protein indicating increased Taxmediated viral gene expression [307]. Stable HBZ expression promoted the IL-2-independent survival of Kit-225 cells (a leukemic T cell line that is solely dependent on exogenous IL-2 for survival) [46] and increased the proliferation of Jurkat $\mathrm{T}$ cells [47]. Knockdown of HBZ expression by shRNA decreased cell proliferation in ATL cell lines, HTLV-1 transformed cell lines, and newly immortalized primary T cells [47]. Hbz RNA, specifically a stem loop structure near the amino terminus of the transcript, and not the protein, increased $\mathrm{T}$ cell proliferation by increasing the transcription of the E2F1 gene [46]. HBZ binds to the Rel homology domain of the $\mathrm{p} 65$ subunit of NF- $\kappa \mathrm{B}$ and degrades p65, thus inhibiting the classical NF- $\mathrm{KB}$ pathway. This function is mechanistically tailored by the increase of E3 ubiquitin ligase, PDLIM2 (PDZ and LIM domain containing protein 2) [297,308]. $\mathrm{NF}-\kappa \mathrm{B}$ functions through a classical and an alternate pathway and both have distinct regulatory functions. The alternate pathway is critical for cellular transformation, while both the pathways regulate anti-apoptotic genes differentially in lymphoma cell lines. HBZ enhances the expression of 
PDLIM2, which suppresses Tax-mediated tumorigenicity by promoting the degradation of Tax. Thus, HBZ suppresses Tax both at the RNA and protein levels.

Recently, Polakowski et al. have demonstrated that siRNA-mediated knockdown of $\mathrm{CBP} / \mathrm{p} 300$ or a truncated form of CBP/p300 containing the KIX domain abrogated the expression of Dickkopf-1 (Dkk-1), a Wnt signaling inhibitor in HBZ transfected cells [309]. Dkk-1 has been shown to play an important role in the development of bone lesions in multiple myeloma. Lytic bone lesions are also a symptom of ATL. DKK-1 mRNA levels were positively correlated with the expression of $\mathrm{Hbz}$ in HTLV-1 infected cell lines. Interestingly, Tax represses the expression of Dkk-1 consistent with the opposing forces of Tax and Hbz within the cell. Taken together, in the late stages of ATL, when Tax is repressed, HBZ supports cell proliferation and the maintenance of the leukemic cell.

In vivo studies in rabbits revealed a significant reduction in proviral load and attenuated antibody response against the viral proteins correlating with the loss of HBZ function [299]. Proviral load was decreased by 5-to-50-fold as early as two weeks post infection in these animals. Kinetic analyses of viral gene expression confirmed the in vitro data that $\mathrm{Hbz}$ mRNA levels were low early after infection and then increased to a stable plateau. This trend was similar to that of the proviral loads and was the reverse of the tax/rex mRNA levels [307]. Thus, HBZ plays an important function in viral persistence. There was an increase in $\mathrm{CD}^{+} \mathrm{T}$ cells in the spleens of transgenic mice expressing $\mathrm{HBZ}$ under the control of the mouse CD4 promoter/enhancer [46]. Another study with NOD/SCID ${ }^{\gamma \text { chain-/. }}$ mice showed that HBZ knockdown in a transformed $\mathrm{T}$ cell line significantly reduced tumor formation and organ infiltration [47]. Together, these two studies confirm that HBZ is essential for promoting $\mathrm{T}$ cell proliferation.

\section{Combined mechanisms of Tax and HBZ in HTLV-1-induced oncogenesis}

A number of mechanisms involving Tax and HBZ have been demonstrated to play a role in HTLV-1-induced oncogenesis (Figure 2). Tax is indispensable for the transformation process induced in HTLV-1 infected cells. However, once transformed, these cells do not require Tax to maintain their leukemic state [184,310]. Tax is detected only in about $40 \%$ of ATL patients [311]. In approximately $10 \%$ of ATL cases, genetic changes in tax have been documented; DNA methylation of tax has been shown in another $15 \%$ of ATL patients; and deletion of the 5'LTR and promoter region has been shown in an additional $27 \%$ of ATL cases [311-316]. In addition, p30 has been shown to repress viral replication at the post-transcriptional level by binding to and retaining tax/rex mRNA in the nucleus $[38,103]$. By suppressing Tax protein expression, p30 attenuates HTLV-1 transcription. More recently, it was reported that $\mathrm{p} 30$ and the positive post-transcriptional regulator Rex form ribonucleoprotein complexes specifically on tax/rex mRNA [317]. Together, these data suggest that p30 may govern the switch between viral latency and replication.

In HTLV-1, the 3'LTR is identical to the 5'LTR. Both carry the TxRE sequences that have the enhancer elements for transcription. However, the enhancing elements of the antisense transcript are much weaker than the sense transcript. This could be part of the reason why $\mathrm{Hbz}$ is detected during the later stages of HTLV infection, unlike tax/rex and gag/pol, which are expressed at high levels during the early stages of infection. Expression of HBZ is correlated positively with proviral loads and negatively with tax/rex and gag/pol expression [307]. HBZ expression also is correlated positively 
with disease severity in ATL and HAM/TSP, suggesting a role in pathogenesis [46,293]. HBZ was detected in all ATL cells, including those that lacked Tax expression. As mentioned above, the absence of Tax in these cells is attributed to genetic changes in the tax gene and/or the 5'LTR. Neither the $\mathrm{Hbz}$ gene nor the 3'LTR are affected by any of these epigenetic silencing mechanisms. Miyazaki et al. showed that in one ATL case, the polyadenylation site of $\mathrm{Hbz}$ gene was deleted. However, the $\mathrm{Hbz}$ gene utilized a downstream polyadenylation signal for transcription [316].

Tax initially increases hTERT expression facilitating lifespan extension and immortalization of cells. Once the virus establishes persistence, Tax represses hTERT via an E-box present in the hTERT promoter probably through competition for $\mathrm{CBP} / \mathrm{p} 300$, and thus favors accumulation of chromosomal rearrangements and then the transformation of the infected cells towards a malignant phenotype. Subsequent epigenetic silencing of Tax in the leukemic cells reactivates hTERT, which in turn, stimulates the proliferative potential of the infected cells leading to ATL. The reactivation of hTERT is a key event in the induction of ATL progression, which is probably tailored by HBZ [302].

Another possible mechanism that could cause epigenetic silencing has been elucidated recently by Fan et al. [318]. They showed that HTLV-1 is prone to RNA editing by human APOBEC3G during reverse transcription, although the editing is at a low frequency. The authors have attributed the nonsense mutations in the plus strand of the proviral DNA coding for env, tax, p13 and p30 to be responsible for the reduced viral gene expression in these cells. The generation of nonsense mutations does not affect the $\mathrm{Hbz}$ gene, which codes from the minus strand. Moreover, there are very few mutation sites in the opposite strand of the HBZ coding region. Therefore, the functional activity of HBZ is not affected. It also was shown that these mutations occur both in ATL cells and HTLV-1 infected cells from asymptomatic carriers, indicating that these mutations do not occur during oncogenesis but are present even during the carrier state. The mutations were present in the leukemic cells and not in the non-leukemic HTLV-1 infected cells, suggesting that there is a selection for these cells during leukemogenesis, which likely favors the virus by promoting immune evasion [318]. Evidence from another group suggests that the 5'LTR deletion occurred before integration in 8/12 ATL cases and after integration in 4/12 ATL cases. This deletion was detected in $3.9 \%$ of the carriers and in $27.8 \%$ of ATL patients. In these defective proviruses, the second exons of the tax, rex and p30 genes were frequently deleted, and thus Tax-mediated activation of NF- $\kappa \mathrm{B}$ and CREB pathways was abrogated. In all these cases, the coding sequences of the $\mathrm{Hbz}$ gene were intact [316].

Taken together, the possible mechanism of HTLV-1-induced oncogenesis suggests that Tax is expressed initially to induce transformation and cell proliferation. Tax-specific CTLs mediate the death of virus infected cells. Thus, the virus is forced to down-regulate Tax expression to below detectable levels by the expression of HBZ in order to persist in the host. Since HBZ-specific CTLs do not lyse ATL cells and HBZ can promote and maintain the leukemic state of these cells, this mechanism ought to be favored by the virus in order to evade immune surveillance and continue to persist in the host. However, why it would be in the best interest of the virus to cause cancer, which is a dead end situation for itself, although in a very small percentage of infected individuals, is still an unanswered question. 
Figure 2. A schematic model illustrating the possible mechanisms by which HTLV-1 succumbs to and evades the host immune system. The sequence of events is labeled with Arabic numerals. 1: attachment and entry of a virion into a target cell; 2: the capsid uncoats releasing the viral RNA; 3: low frequency editing of the genomic RNA by APOBEC3G, one possible mechanism for epigenetic silencing; 4: reverse transcription into double-stranded DNA; 5: proviral integration into the host chromosome; 6: initial transcription and export of completely/doubly spliced viral mRNA by host cellular factors; 7: favorable translation of Tax due to a strong Kozak sequence; 8: Tax transactivation of the viral LTR to promote viral gene expression; 9: Tax increases cellular transcription, promotes DNA damage, regulates cell cycle and induces proliferation of genetically altered cells. Tax also increases hTERT function initially to induce transformation of virus infected cells, but subsequently down-modulates hTERT to accumulate chromosomal rearrangements and maintain transformation; 10: high expression of Tax by virus infected cells results in their elimination by Tax-specific CTL induced cell death; 11: expression of viral accessory proteins like p12 and p13 facilitates viral persistence in the host. Additionally, the sparsely elicited HBZ-specific CTLs do not lyse ATL cells due to the low HBZ protein expression levels in all ATL cell lines and HTLV-1 transformed cell lines. This helps in immune evasion and viral persistence; 12: the accessory protein, p30, translocates to the nucleus and forms ribonucleoprotein complexes with Rex to retain tax/rex mRNA in the nucleus, and thus represses the expression of Tax; 13: HBZ represses Tax at the transcriptional level by competing for CREB-2 and CBP/p300, and at the protein level by enhancing the expression of PDLIM2. Furthermore, HBZ complements for the reduced activity of Tax by activating cellular factors to induce transformation and proliferation of genetically unstable cells; 14:epigenetic silencing mechanisms also result in decreased Tax expression levels facilitating viral persistence; 15: reduced Tax and increased HBZ levels reactivate hTERT, which is a key event in the progression of ATL.

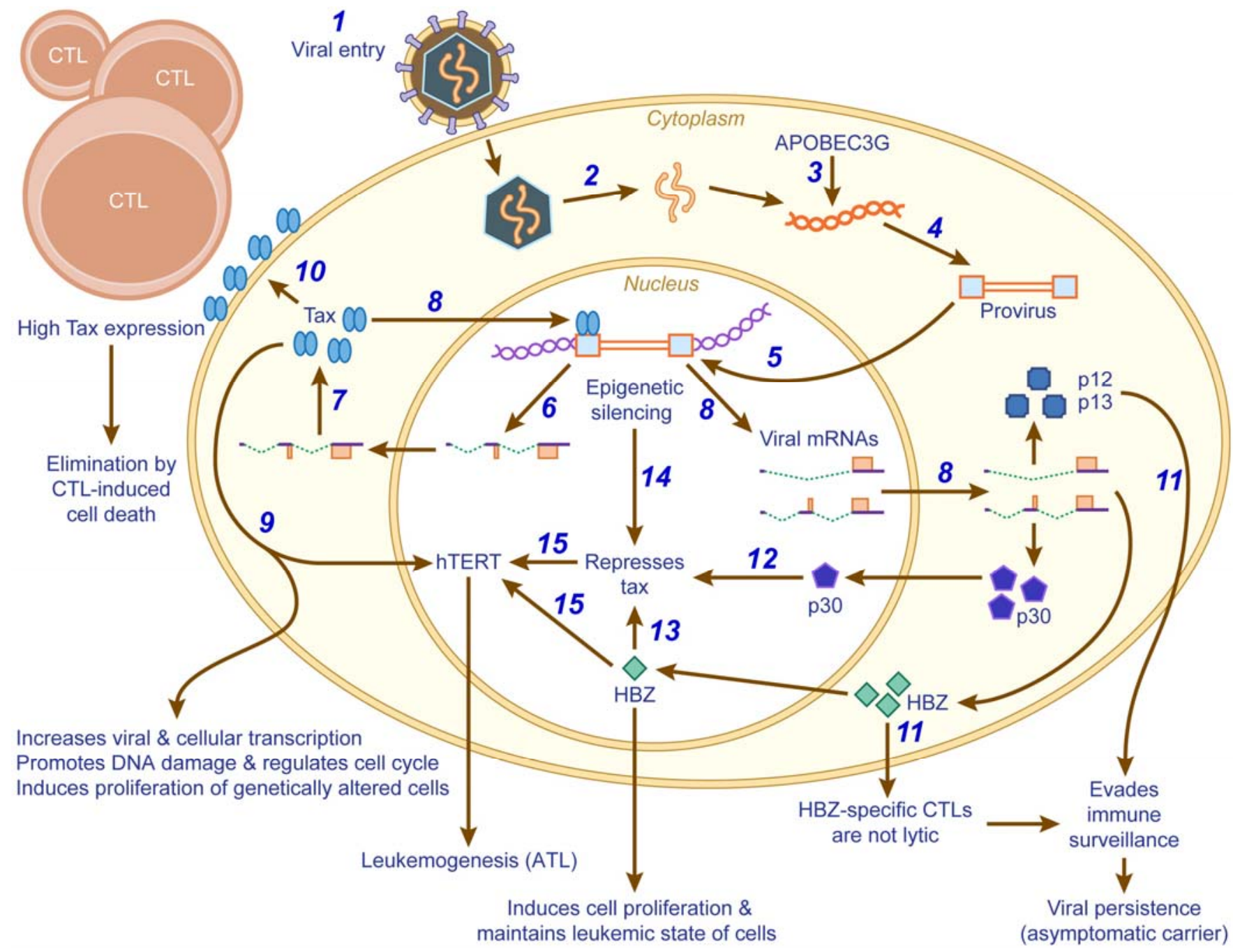




\section{Conclusions}

HTLVs are complex retroviruses with unique proteins that have oncogenic potential. There are four known strains of HTLV, HTLV-1, HTLV-2, HTLV-3, HTLV-4; only HTLV-1 and HTLV-2 have been consistently associated with disease in humans. HTLV-1 mainly causes ATL and HAM/TSP. HTLV-2 is not etiologically oncogenic and has been associated with some neurological disorders. HTLV-3 and HTLV-4 were identified in African primate hunters without any subsequent etiological disease associations so far.

A complete understanding of the functions of the viral genes would give insights into the pathogenic mechanisms by which HTLV-1 induces oncogenesis. In this review we summarize the data published so far in this field with pertinent comparisons to HTLV-2, the non-leukemic counterpart. Like simple retroviruses, HTLV-1 expresses structural and enzymatic proteins for its assembly and maturation, and for entry into new target cells. HTLV-1 also expresses regulatory and accessory proteins that are essential for viral persistence, immune evasion and ultimately, leukemogenesis. Although, the exact mechanisms and pathways have not been fully elucidated, much is known thus far. For instance, Tax is expressed in the early stages of infection to establish viral transcription and induce $\mathrm{T}$ cell transformation by regulating cellular transcription factors, inducing G1 to S phase transition and DNA damage resulting in genetic instability, and promoting proliferation of genetically altered (leukemic) cells. Subsequently, HBZ suppresses Tax expression to evade immune elimination by Taxspecific CTLs, and also complements for Tax to support proliferation; it provides a second oncogenic signal required for the maintenance of the leukemic cell. Further investigations are warranted to determine the additional events in the minor population that progresses to ATL.

\section{Acknowledgements}

We thank Tim Vojt for figure preparation and Kate Hayes-Ozello for editing the manuscript.

\section{References and Notes}

1. Poiesz, B.J.; Ruscetti, F.W.; Gazdar, A.F.; Bunn, P.A.; Minna, J.D.; Gallo, R.C. Detection and isolation of type $\mathrm{C}$ retrovirus particles from fresh and cultured lymphocytes of a patient with cutaneous T-cell lymphoma. Proc. Natl. Acad. Sci. U. S. A. 1980, 77, 7415-7419.

2. Hinuma, Y.; Nagata, K.; Hanaoka, M.; Nakai, M.; Matsumoto, T.; Kinoshita, K.-I.; Shirakawa, S.; Miyoshi, I. Adult T-cell leukemia: Antigen in an ATL cell line and detection of antibodies to the antigen in human sera. Proc. Natl. Acad. Sci. U. S. A. 1981, 78, 6476-6480.

3. Yoshida, M.; Miyoshi, I.; Hinuma, Y. Isolation and characterization of retrovirus from cell lines of human adult T-cell leukemia and its implication in the disease. Proc. Natl. Acad. Sci. U. S. A. 1982, 79, 2031-2035.

4. Kalyanaraman, V.S.; Sarngadharan, M.G.; Robert-Guroff, M.; Miyoshi, I.; Golde, D.; Gallo, R.C. A new subtype of human T-cell leukemia virus (HTLV-II) associated with a T-cell variant of hairy cell leukemia. Science 1982, 218, 571-573.

5. Saxon, A.; Stevens, R.H.; Golde, D.W. T-lymphocyte variant of hairy-cell leukemia. Ann. Intern. Med. 1978, 88, 323-326. 
6. Saxon, A.; Stevens, R.H.; Quan, S.G.; Golde, D.W. Immunologic characterization of hairy cell leukemias in continuous culture. J. Immunol. 1978, 120, 777-782.

7. Hjelle, B.; Appenzeller, O.; Mills, R.; Alexander, S.; Torrez-Martinez, N.; Jahnke, R.; Ross, G. Chronic neurodegenerative disease associated with HTLV-II infection. Lancet 1992, 339, 645-646.

8. Hanon, E.; Stinchcombe, J.C.; Saito, M.; Asquith, B.E.; Taylor, G.P.; Tanaka, Y.; Weber, J.N.; Griffiths, G.M.; Bangham, C.R. Fratricide among CD8(+) T lymphocytes naturally infected with human T cell lymphotropic virus type I. Immunity 2000, 13, 657-664.

9. Hoxie, J.A.; Matthews, D.M.; Cines, D.B. Infection of human endothelial cells by human T-cell leukemia virus type I. Proc. Natl. Acad. Sci. U. S. A. 1984, 81, 7591-7595.

10. Koyanagi, Y.; Itoyama, Y.; Nakamura, N.; Takamatsu, K.; Kira, J.; Iwamasa, T.; Goto, I.; Yamamoto, N. In vivo infection of human T-cell leukemia virus type I in non-T cells. Virology 1993, 196, 25-33.

11. Macatonia, S.E.; Cruickshank, J.K.; Rudge, P.; Knight, S.C. Dendritic cells from patients with tropical spastic paraparesis are infected with HTLV-1 and stimulate autologous lymphocyte proliferation. AIDS Res. Hum. Retroviruses 1992, 8, 1699-1706.

12. Lee, T.H.; Coligan, J.E.; Homma, T.; McLane, M.F.; Tachibana, N.; Essex, M. Human T-cell leukemia virus-associated membrane antigens (HTLV-MA): Identity of the major antigens recognized after virus infection. Proc. Natl. Acad. Sci. U. S. A. 1984, 81, 3856-3860.

13. Nam, S.H.; Kidokoro, M.; Shida, H.; Hatanaka, M. Processing of gag precursor polyprotein of human T-cell leukemia virus type I by virus-encoded protease. J. Virol. 1988, 62, 3718-3728.

14. Paine, E.; Gu, R.; Ratner, L. Structure and expression of the human T-cell leukemia virus type 1 envelope protein. Virology 1994, 199, 331-338.

15. Cann, A.J.; Rosenblatt, J.D.; Wachsman, W.; Shah, N.P.; Chen, I.S.Y. Identification of the gene responsible for human T-cell leukemia virus transcriptional regulation. Nature 1985, 318, 571-574.

16. Felber, B.K.; Paskalis, H.; Kleinman-Ewing, C.; Wong-Staal, F.; Pavlakis, G.N. The pX protein of HTLV-I is a transcriptional activator of its long terminal repeats. Science 1985, 229, 675-679.

17. Inoue, J.I.; Yoshida, M.; Seiki, M. Transcriptional $\left(\mathrm{p} 40^{\mathrm{x}}\right)$ and post-transcriptional (p27 $7^{\mathrm{xIII}}$ ) regulators are required for the expression and replication of human T-cell leukemia virus type I genes. Proc. Natl. Acad. Sci. U. S. A. 1987, 84, 3653-3657.

18. Leung, K.; Nabel, G.J. HTLV-I transactivator induces interleukin-2 receptor expression through an NF B-like factor. Nature 1988, 333, 776-778.

19. Mulloy, J.C.; Kislyakova, T.; Cereseto, A.; Casareto, L.; LoMonico, A.; Fullen, J.; Lorenzi, M.V.; Cara, A.; Nicot, C.; Giam, C.; Franchini, G. Human T-cell lymphotropic/leukemia virus type 1 Tax abrogates p53- induced cell cycle arrest and apoptosis through its CREB/ATF functional domain. J. Virol. 1998, 72, 8852-8860.

20. Ressler, S.; Morris, G.F.; Marriott, S.J. Human T-cell leukemia virus type 1 Tax transactivates the human proliferating cell nuclear antigen promoter. J. Virol. 1997, 71, 1181-1190.

21. Schmitt, I.; Rosin, O.; Rohwer, P.; Gossen, M.; Grassmann, R. Stimulation of cyclin-dependent kinase activity and G1- to S-phase transition in human lymphocytes by the human T-cell leukemia/lymphotropic virus type 1 Tax protein. J. Virol. 1998, 72, 633-640. 
22. Siekevitz, M.; Feinberg, M.B.; Holbrook, N.; Wong-Staal, F.; Greene, W.C. Activation of interleukin 2 and interleukin 2 receptor (Tac) promoter expression by the trans-activator (tat) gene product of human T-cell leukemia virus, type I. Proc. Natl. Acad. Sci. U. S. A. 1987, 84, 5389-5393.

23. Kashanchi, F.; Brady, J.N. Transcriptional and post-transcriptional gene regulation of HTLV-1. Oncogene 2005, 24, 5938-5951.

24. Grassmann, R.; Berchtolds, S.; Radant, I.; Alt, M.; Fleckenstein, B.; Sodroski, J.G.; Haseltine, W.A.; Ramstedt, U. Role of the human T-cell leukemia virus type $1 \mathrm{X}$ region proteins in immortalization of primary human lymphocytes in culture. J. Virol. 1992, 66, 4570-4575.

25. Grassmann, R.; Dengler, C.; Muller-Fleckenstein, I.; Fleckenstein, B.; McGuire, K.; Dokhelar, M.-C.; Sodroski, J.G.; Haseltine, W.A. Transformation to continuous growth of primary human T lymphocytes by human T-cell leukemia virus type I X-region genes transduced by a Herpesvirus saimiri vector. Proc. Natl. Acad. Sci. U. S. A. 1989, 86, 3351-3355.

26. Nerenberg, M.; Hinrichs, S.M.; Reynolds, R.K.; Khoury, G.; Jay, G. The tat gene of human Tlymphotrophic virus type I induces mesenchymal tumors in transgenic mice. Science 1987, 237, 1324-1329.

27. Tanaka, A.; Takahashi, C.; Yamaoka, S.; Nosaka, T.; Maki, M.; Hatanaka, M. Oncogenic transformation by the tax gene of human T-cell leukemia virus type I in vitro. Proc. Natl. Acad. Sci. U. S. A. 1990, 87, 1071-1075.

28. Yamaoka, S.; Tobe, T.; Hatanaka, M. Tax protein of human T-cell leukemia virus type I is required for mantenance of the transformed phenotype. Oncogene 1992, 7, 433-437.

29. Robek, M.D.; Ratner, L. Immortalization of CD4+ and CD8+ T-lymphocytes by human T-cell leukemia virus type 1 Tax mutants expressed in a functional molecular clone. J. Virol. 1999, 73, 4856-4865.

30. Ross, T.M.; Narayan, M.; Fang, Z.Y.; Minella, A.C.; Green, P.L. Tax transactivation of both $\mathrm{NF} B$ and CREB/ATF is essential for Human T-cell leukemia virus type 2-mediated transformation of primary human T-cells. J. Virol. 2000, 74, 2655-2662.

31. Ross, T.M.; Pettiford, S.M.; Green, P.L. The tax gene of human T-cell leukemia virus type 2 is essential for transformation of human T lymphocytes. J. Virol. 1996, 70, 5194-5202.

32. Younis, I.; Green, P.L. The human T-cell leukemia virus Rex protein. Front. Biosci. 2005, 10, 431-445.

33. Bartoe, J.T.; Albrecht, B.; Collins, N.D.; Robek, M.D.; Ratner, L.; Green, P.L.; Lairmore, M.D. Functional role of $\mathrm{pX}$ open reading frame II of human T-lymphotropic virus type 1 in maintenance of viral loads in vivo. J. Virol. 2000, 74, 1094-1100.

34. Collins, N.D.; Newbound, G.C.; Albrecht, B.; Beard, J.; Ratner, L.; Lairmore, M.D. Selective ablation of human T-cell lymphotropic virus type $1 \mathrm{p} 12 \mathrm{I}$ reduces viral infectivity in vivo. Blood 1998, 91, 4701-4707.

35. Derse, D.; Mikovits, J.; Ruscetti, F. X-I and X-II open reading frames of HTLV-I are not required for virus replication or for immortalization of primary T-cells in vitro. Virology 1997, 237, 123-128. 
36. Valeri, V.W.; Hryniewicz, A.; Andresen, V.; Jones, K.; Fenizia, C.; Bialuk, I.; Chung, H.K.; Fukumoto, R.; Washington Parks, R.; Ferrari, M.G.; Nicot, C.; Cecchinato, V.; Ruscetti, F.; Franchini, G. Requirement of the human T-cell leukemia virus p12 and p30 genes for infectivity of human dendritic cells and macaques but not rabbits. Blood 2010, doi: 10.1182/blood-2010-05284141.

37. Albrecht, B.; Collins, N.D.; Burniston, M.T.; Nisbet, J.W.; Ratner, L.; Green, P.L.; Lairmore, M.D. Human T-lymphotropic virus type 1 open reading frame I p12(I) is required for efficient viral infectivity in primary lymphocytes. J. Virol. 2000, 74, 9828-9835.

38. Younis, I.; Khair, L.; Dundr, M.; Lairmore, M.D.; Franchini, G.; Green, P.L. Repression of human T-cell leukemia virus type 1 and 2 replication by a viral mRNA-encoded posttranscriptional regulator. J. Virol. 2004, 78, 11077-11083.

39. Zhang, W.; Nisbet, J.W.; Bartoe, J.T.; Ding, W.; Lairmore, M.D. Human T-lymphotropic virus type $1 \mathrm{p} 30^{\mathrm{II}}$ functions as a transcription factor and differentially modulates CREB-responsive promoters. J. Virol. 2000, 74, 11270-11277.

40. Nicot, C.; Harrod, R.L.; Ciminale, V.; Franchini, G. Human T-cell leukemia/lymphoma virus type 1 nonstructural genes and their functions. Oncogene 2005, 24, 6026-6034.

41. Gaudray, G.; Gachon, F.; Basbous, J.; Biard-Piechaczyk, M.; Devaux, C.; Mesnard, J. The complementary strand of the human T-cell leukemia virus type 1 RNA genome encodes a bZIP transcription factor that down-regulates viral transcription. J. Virol. 2002, 76, 12813-12822.

42. Basbous, J.; Arpin, C.; Gaudray, G.; Piechaczyk, M.; Devaux, C.; Mesnard, J. HBZ factor of HTLV-1 dimerizes with transcription factors JunB and c-Jun and modulates their transcriptional activity. J. Biol. Chem. 2003, 278, 43620-43627.

43. Clerc, I.; Polakowski, N.; Andre-Arpin, C.; Cook, P.; Barbeau, B.; Mesnard, J.M.; Lemasson, I. An interaction between the human $\mathrm{T}$ cell leukemia virus type 1 basic leucine zipper factor (HBZ) and the KIX domain of p300/CBP contributes to the down-regulation of tax-dependent viral transcription by HBZ. J. Biol. Chem. 2008, 283, 23903-23913.

44. Thebault, S.; Basbous, J.; Hivin, P.; Devaux, C.; Mesnard, J.M. HBZ interacts with JunD and stimulates its transcriptional activity. FEBS Lett. 2004, 562, 165-170.

45. Lemasson, I.; Lewis, M.R.; Polakowski, N.; Hivin, P.; Cavanagh, M.H.; Thebault, S.; Barbeau, B.; Nyborg, J.K.; Mesnard, J.M. Human T-cell leukemia virus type 1 (HTLV-1) bZIP protein interacts with the cellular transcription factor CREB to inhibit HTLV-1 transcription. J. Virol. 2007, 81, 1543-1553.

46. Satou, Y.; Yasunaga, J.; Yoshida, M.; Matsuoka, M. HTLV-I basic leucine zipper factor gene mRNA supports proliferation of adult T cell leukemia cells. Proc. Natl. Acad. Sci. U. S. A. 2006, 103, 720-725.

47. Arnold, J.; Zimmerman, B.; Li, M.; Lairmore, M.D.; Green, P.L. Human T-cell Leukemia Virus Type-1 Antisense-encoded Gene, Hbz, Promotes T Lymphocyte Proliferation. Blood 2008, 112, 3788-3797.

48. Kinoshita, K.; Amagasaki, T.; Ikeda, S.; Suzuyama, J.; Toriya, K.; Nishino, K.; Tagawa, M.; Ichimaru, M.; Kamihira, S.; Yamada, Y.; Momita, S.; Kusano, M.; Morikawa, T.; Fujita, S.; Ueda, Y.; Ito, N.; Yoshida, M. Preleukemic state of adult T cell leukemia: Abnormal T lymphocytosis induced by human adult $\mathrm{T}$ cell leukemia-lymphoma virus. Blood 1985, 66, 120-127. 
49. Kinoshita, K.; Hino, S.; Amagasaki, T.; Yamada, Y.; Kamihira, S.; Ichimaru, M.; Munehira, T.; Hinuma, Y. Development of adult T-cell leukemia-lymphoma (ATL) in two anti-ATL associated antigen-positive healthy adults. Gann 1982, 73, 684-685.

50. Matsumoto, M.; Nomuta, K.; Matsumoto, T.; Nishioka, K.; Harada, S.; Forusho, H.; Kikuchi, H.; Kato, Y.; Utsonomiya, A.; Uematsu, T.; Iwahashi, M.; Hashimoto, S.; Yunoki, K. Adult T-cell leukemia-lymphoma in Kagoshima District, southwestern Japan: Clinical and hematological characteristics. Jpn. J. Clin. Oncol. 1979, 9, 325-336.

51. Shimoyama, M. Diagnostic criteria and classification of clinical subtypes of adult T-cell leukemia-lymphoma. A report from the lymphoma study group (1984-1987). Br. J. Haematol. 1991, 79, 437.

52. Blattner, W.A.; Gibbs, W.N.; Saxinger, C.; Robert-Guroff, M.; Clark, J.; Lofters, W.; Hanchard, B.; Campbell, M.; Gallo, R.C. Human T-cell leukaemia/lymphoma virus-associated lymphoreticular neoplasia in Jamaica. Lancet 1983, ii, 61-64.

53. Kitajima, I.; Yamamoto, K.; Sato, K.; Nakajima, Y.; Nakajima, T.; Maruyama, I.; Osame, M.; K., N. Detection of human T cell lymphotropic virus type I proviral DNA and its gene expression in synovial cells in chronic inflammatory arthropathy. J. Clin. Invest. 1991, 88, 1315-1322.

54. Nishioka, K.; Nakajima, T.; Hasunuma, T.; Sato, K. Rheumatic manifestation of human leukemia virus infection. Rheum. Dis. Clin. North Am. 1993, 19, 489-503.

55. Sato, K.; Maruyama, I.; Maruyama, Y.; Kitajima, I.; Nakajima, Y.; Higaki, M.; Yamamoto, K.; Miyasaka, N.; Osame, M.; Nishioka, K. Arthritis in patients infected with human T lymphotropic virus type I. Clinical and immunopathologic features Arthritis Rheum. 1991, 34, 714-721.

56. Mochizuki, M.; Yamaguchi, K.; Takatsuki, K.; Watanabe, T.; Mori, S.; Tajima, K. HTLV-I and uveitis. Lancet 1992, 339, 1110.

57. Nakao, K.; Matsumoto, M.; Ohda, N. Seroprevalence of antibodies to HTLV-I in patients with ocular disorders. Br. J. Ophthalmol. 1991, 75, 76-78.

58. Gessain, A.; Jouanelle, A.; Escarmant, P.; Celander, A.; Schaffar-Deshayes, L.; G., d.-T. HTLV antibodies in patients with non-Hodgkins lymphoma in Martinique. Lancet 1984, i, 1183-1184.

59. Gibbs, W.N.; Lofters, W.S.; Campbell, M.; Hanchard, B.; LaGrenade, L.; Cranston, B.; Hendriks, J.; Jaffe, E.S.; Saxinger, C.; Robert-Guroff, M.; al., e. Non-Hodgkin lymphoma in Jamaica and its relation to adult T-cell leukemia-lymphoma. Ann. Intern. Med. 1987, 106, 361-368.

60. Matsuzaki, H.; Asou, N.; Kawaguchi, Y.; Hata, H.; Yoshinaga, T.; Kinuwaki, E.; Ishii, T.; Yamaguchi, K.; Takatsuki, K. Human T-cell leukemia virus type 1 associated with small cell lung cancer. Cancer 1990, 66, 1763-1768.

61. Starkebaum, G.; Kalyanaraman, V.S.; Kidd, P.G.; Loughran Jr, T.P.; Kadin, M.E.; Singer, J.W.; Ruscetti, F.W. Serum reactivity to human T-cell leukemia/lymphoma virus type I proteins in patients with large granular lymphocytic leukemia. Lancet 1987, i, 596-598.

62. Proietti, F.A.; Carneiro-Proietti, A.B.; Catalan-Soares, B.C.; Murphy, E.L. Global epidemiology of HTLV-I infection and associated diseases. Oncogene 2005, 24, 6058-6068.

63. Araujo, A.; Hall, W.W. Human T-lymphotropic virus type II and neurological disease. Ann. Neurol. 2004, 56, 10-19. 
64. Orland, J.R.; Engstrom, J.; Fridey, J.; Sacher, R.A.; Smith, J.W.; Nass, C.; Garratty, G.; Newman, B.; Smith, D.; Wang, B.; Loughlin, K.; Murphy, E.L. Prevalence and clinical features of HTLV neurologic disease in the HTLV Outcomes Study. Neurology 2003, 61, 1588-1594.

65. de The, G.; Kazanji, M. An HTLV-I/II vaccine: from animal models to clinical trials. J. Acquir. Immune Defic. Syndr. Hum. Retrovirol. 1996, 13 (Suppl. 1), S191-198.

66. Clark, J.W.; Robert-Guroff, M.; Ikehara, O.; Henzan, E.; Blattner, W.A. Human T-cell leukemialymphoma virus type 1 and adult T-cell leukemia-lymphoma in Okinawa. Cancer Res. 1985, 45, 2849-2852.

67. Wiktor, S.Z.; Piot, P.; Mann, J.M.; Nzilambi, N.; Francis, H.; Vercauteren, G.; Blattner, W.A.; Quinn, T.C. Human T cell lymphotropic virus type I (HTLV-I) among female prostitutes in Kinshasa, Zaire. J. Infect. Dis. 1990, 161, 1073-1077.

68. Delaporte, E.; Dupont, A.; Peeters, M.; Josse, R.; Merlin, M.; Schrijvers, D.; Hamono, B.; Bedjabaga, L.; Cheringou, H.; Boyer, F.; et al. Epidemiology of HTLV-I in Gabon (Western Equatorial Africa). Int. J. Cancer 1988, 42, 687-689.

69. Blattner, W.A.; Kalyanaraman, V.S.; Robert-Guroff, M.; Lister, T.A.; Galton, D.A.G.; Sarin, P.S.; Crawford, M.H.; Catovsky, D.; Greaves, M.; Gallo, R.C. The human type-C retrovirus, HTLV, in blacks from the Caribbean region, and relationship to adult T-cell leukemia/lymphoma. Int. J. Cancer 1982, 30, 257-264.

70. Nogueira, C.M.; Cavalcanti, M.; Schechter, M.; Ferreira, O.C., Jr. Human T lymphotropic virus type I and II infections in healthy blood donors from Rio de Janeiro, Brazil. Vox Sang 1996, 70, 47-48.

71. Yanagihara, R.; Jenkins, C.L.; Alexander, S.S.; Mora, C.A.; Garruto, R.M. Human T lymphotropic virus type I infection in Papua New Guinea: high prevalence among the Hagahai confirmed by western analysis. J. Infect. Dis. 1990, 162, 649-654.

72. Meytes, D.; Schochat, B.; Lee, H.; Nadel, G.; Sidi, Y.; Cerney, M.; Swanson, P.; Shaklai, M.; Kilim, Y.; Elgat, M.; et al. Serological and molecular survey for HTLV-I infection in a high-risk Middle Eastern group. Lancet 1990, 336, 1533-1535.

73. Hashimoto, K.; Lalkaka, J.; Fujisawa, J.; Singhal, B.S.; Machigashira, K.; Kubota, R.; Suehara, M.; Osame, M.; Yoshida, M. Limited sequence divergence of HTLV-I of Indian HAM/TSP patients from a prototype Japanese isolate. AIDS Res. Hum. Retroviruses 1993, 9, 495-498.

74. Singhal, B.S.; Lalkaka, J.A.; Sonoda, S.; Hashimoto, K.; Nomoto, M.; Kubota, R.; Osame, M. Human T-lymphotropic virus type I infections in western India. AIDS 1993, 7, 138-139.

75. Lee, H.; Swanson, P.; Shorty, V.S.; Zack, J.A.; Rosenblatt, J.D.; Chen, I.S.Y. High rate of HTLVII infection in seropositive IV drug abusers from New Orleans. Science 1989, 244, 471-475.

76. Krook, A.; Blomberg, J. HTLV-II among injecting drug users in Stockholm. Scand. J. Infect. Dis. 1994, 26, 129-132.

77. Gabbai, A.A.; Bordin, J.O.; Vieira-Filho, J.P.; Kuroda, A.; Oliveira, A.S.; Cruz, M.V.; Ribeiro, A.A.; Delaney, S.R.; Henrard, D.R.; Rosario, J.; et al. Selectivity of human T lymphotropic virus type-1 (HTLV-1) and HTLV-2 infection among different populations in Brazil. Am. J. Trop. Med. Hyg. 1993, 49, 664-671. 
78. Fukushima, Y.; Takahashi, H.; Hall, W.W.; Nakasone, T.; Nakata, S.; Song, P.; Dinh Duc, D.; Hien, B.; Nguyen, X.Q.; Ngoc Trinh, T.; et al. Extraordinary high rate of HTLV type II seropositivity in intravenous drug abusers in south Vietnam. AIDS Res. Hum. Retroviruses 1995, 11, 637-645.

79. Calattini, S.; Chevalier, S.A.; Duprez, R.; Bassot, S.; Froment, A.; Mahieux, R.; Gessain, A. Discovery of a new human T-cell lymphotropic virus (HTLV-3) in Central Africa. Retrovirol. 2005, 2, 30 .

80. Wolfe, N.D.; Heneine, W.; Carr, J.K.; Garcia, A.D.; Shanmugam, V.; Tamoufe, U.; Torimiro, J.N.; Prosser, A.T.; Lebreton, M.; Mpoudi-Ngole, E.; McCutchan, F.E.; Birx, D.L.; Folks, T.M.; Burke, D.S.; Switzer, W.M. Emergence of unique primate T-lymphotropic viruses among central African bushmeat hunters. Proc. Natl. Acad. Sci. U. S. A. 2005, 102, 7994-7999.

81. Wiktor, S.Z.; Pate, E.J.; Murphy, E.L.; Palker, T.J.; Champegnie, E.; Ramlal, A.; Cranston, B.; Hanchard, B.; Blattner, W.A. Mother-to-child transmission of human T-cell lymphotropic virus type I (HTLV-I) in Jamaica: association with antibodies to envelope glycoprotein (gp46) epitopes. J. Acquir. Immune Defic. Syndr. 1993, 6, 1162-1167.

82. Takahashi, K.; Takezaki, T.; Oki, T.; Kawakami, K.; Yashiki, S.; Fujiyoshi, T.; Usuku, K.; Mueller, N.; Osame, M.; Miyata, K.; et al. Inhibitory effect of maternal antibody on mother-tochild transmission of human T-lymphotropic virus type I. The Mother-to-Child Transmission Study Group. Int. J. Cancer 1991, 49, 673-677.

83. Nyambi, P.N.; Ville, Y.; Louwagie, J.; Bedjabaga, I.; Glowaczower, E.; Peeters, M.; Kerouedan, D.; Dazza, M.; Larouze, B.; van der Groen, G.; Delaporte, E. Mother-to-child transmission of human T-cell lymphotropic virus types I and II (HTLV-I/II) in Gabon: a prospective follow-up of 4 years. J. Acquir. Immune Defic. Syndr. Hum. Retrovirol. 1996, 12, 187-192.

84. Kusuhara, K.; Sunoda, S.; Takahashi, K.; Tokugawa, K.; Fukushige, J.; Ueda, K. Mother to child transmission of human T cell leukemia virus type I (HTLV-I): A fifteen year followup study in Okinawa, Japan. Int. J. Cancer 1987, 40, 755-757.

85. Kajiyama, W.; Kashiwagi, S.; Ikematsu, H.; Hayashi, J.; Nomura, H.; Okochi, K. Intrafamilial transmission of adult T cell leukemia virus. J. Infect. Dis. 1986, 154, 851-857.

86. Kaplan, J.E.; Khabbaz, R.F.; Murphy, E.L.; Hermansen, S.; Roberts, C.; Lal, R.; Heneine, W.; Wright, D.; Matijas, L.; Thomson, R.; Rudolph, D.; Switzer, W.M.; Kleinman, S.; Busch, M.; Schreiber, G.B. Male-to-female transmission of human T-cell lymphotropic virus types I and II: association with viral load. The Retrovirus Epidemiology Donor Study Group. J. Acquir. Immune Defic. Syndr. Hum. Retrovirol. 1996, 12, 193-201.

87. Murphy, E.L.; Figueroa, J.P.; Gibbs, W.N.; Brathwaite, A.; Holding-Cobham, M.; Waters, D.; Cranston, B.; Hanchard, B.; Blattner, W.A. Sexual transmission of human T-lymphotropic virus type I (HTLV-I). Ann. Intern. Med. 1989, 111, 555-560.

88. Schreiber, G.B.; Murphy, E.L.; Horton, J.A.; Wright, D.J.; Garfein, R.; Chien, H.C.; Nass, C.C. Risk factors for human T-cell lymphotropic virus types I and II (HTLV-I and -II) in blood donors: the Retrovirus Epidemiology Donor Study. NHLBI Retrovirus Epidemiology Donor Study. J. Acquir. Immune Defic. Syndr. Hum. Retrovirol. 1997, 14, 263-271.

89. Roucoux, D.F.; Murphy, E.L. The epidemiology and disease outcomes of human T-lymphotropic virus type II. AIDS Rev. 2004, 6, 144-154. 
90. Okochi, K.; Sato, H.; Hinuma, Y. A retrospective study on transmission of adult T cell leukemia virus by blood transfusion: Seroconversion in recipients. Vox Sang 1984, 46, 245-253.

91. Donegan, E.; Lee, H.; Operskalski, E.A.; Shaw, G.M.; Kleinman, S.H.; Busch, M.P.; Stevens, C.E.; Schiff, E.R.; Nowicki, M.J.; Hollingsworth, C.G.; et al. Transfusion transmission of retroviruses: human T-lymphotropic virus types I and II compared with human immunodeficiency virus type 1. Transfusion 1994, 34, 478-483.

92. Kamihira, S.; Nakasima, S.; Oyakawa, Y.; Moriuti, Y.; Ichimaru, M.; Okuda, H.; Kanamura, M.; Oota, T. Transmission of human T cell lymphotropic virus type I by blood transfusion before and after mass screening of sera from seropositive donors. Vox Sang 1987, 52, 43-44.

93. Manns, A.; Wilks, R.J.; Murphy, E.L.; Haynes, G.; Figueroa, J.P.; Barnett, M.; Hanchard, B.; Blattner, W.A. A prospective study of transmission by transfusion of HTLV-I and risk factors associated with seroconversion. Int. J. Cancer 1992, 51, 886-891.

94. Gout, O.; Bauloc, M.; Gessain, A.; Semah, F.; Saal, F.; Peries, J.; Cabrol, C.; Foucault-Fretz, C.; Laplane, D.; Sigaux, F. Rapid development of myelopathy after HTLV-I infection acquired by transfusion during cardiac transplantation. New Engl. J. Med. 1990, 322, 383-388.

95. Yamamoto, N.; Okada, M.; Koyanagi, Y.; Kannagi, Y.; Kannagi, M.; Hinuma, Y. Transformation of human leukocytes by cocultivation with an adult $\mathrm{T}$ cell leukemia virus producer cell line. Science 1982, 217, 737-739.

96. Majorovits, E.; Nejmeddine, M.; Tanaka, Y.; Taylor, G.P.; Fuller, S.D.; Bangham, C.R. Human T-lymphotropic virus-1 visualized at the virological synapse by electron tomography. PLoS One 2008, 3, e2251.

97. Jones, K.S.; Petrow-Sadowski, C.; Huang, Y.K.; Bertolette, D.C.; Ruscetti, F.W. Cell-free HTLV1 infects dendritic cells leading to transmission and transformation of CD4(+) T cells. Nat. Med. 2008, 14, 429-436.

98. Osame, M.; Usuku, K.; Izumo, S.; Ijichi, N.; Amitani, H.; Igata, A.; Matsumoto, M.; Tara, M. HTLV-I associated myelopathy, a new clinical entity. Lancet 1986, i, 1031-1032.

99. Green, P.L.; Chen, I.S.Y. Regulation of human T cell leukemia virus expression. FASEB J. 1990, 4, 169-175.

100. Poiesz, B.J.; Poiesz, M.J.; Choi, D. The human T-cell lymphoma/leukemia viruses. Cancer Invest. 2003, 21, 253-277.

101. Rosenblatt, J.D.; Chen, I.S.Y.; Wachsman, W. Infection with HTLV-I and HTLV-II-evolving concepts. Semin. Hematol. 1988, 25, 230-246.

102. Datta, A.; Silverman, L.; Phipps, A.J.; Hiraragi, H.; Ratner, L.; Lairmore, M.D. Human Tlymphotropic virus type-1 p30 alters cell cycle $\mathrm{G} 2$ regulation of $\mathrm{T}$ lymphocytes to enhance cell survival. Retrovirology 2007, 4, 49.

103. Nicot, C.; Dundr, J.M.; Johnson, J.R.; Fullen, J.R.; Alonzo, N.; Fukumoto, R.; Princler, G.L.; Derse, D.; Misteli, T.; Franchini, G. HTLV-1-encoded $\mathrm{p} 30^{\mathrm{II}}$ is a post-transcriptional negative regulator of viral replication. Nat. Med. 2004, 10, 197-201.

104. Baydoun, H.H.; Bellon, M.; Nicot, C. HTLV-1 Yin and Yang: Rex and p30 master regulators of viral mRNA trafficking. AIDS Rev. 2008, 10, 195-204. 
105. Koralnik, I.J.; Fullen, J.; Franchini, G. The p12 $2^{\mathrm{I}}$ p13 ${ }^{\mathrm{II}}$, and $\mathrm{p} 30^{\mathrm{II}}$ proteins encoded by human Tcell leukemia/lymphotropic virus type I open reading frames I and II are localized in three different cellular compartments. J. Virol. 1993, 67, 2360-2366.

106. Ding, W.; Albrecht, B.; Luo, R.; Zhang, W.; Stanley, J.R.; Newbound, G.C.; Lairmore, M.D. Endoplasmic reticulum and cis-Golgi localization of human T- lymphotropic virus type $1 \mathrm{p} 12(\mathrm{I})$ : association with calreticulin and calnexin. J. Virol. 2001, 75, 7672-7682.

107. Johnson, J.M.; Nicot, C.; Fullen, J.; Ciminale, V.; Casareto, L.; Mulloy, J.C.; Jacobson, S.; Franchini, G. Free major histocompatibility complex class I heavy chain is preferentially targeted for degradation by human T-cell leukemia/lymphotropic virus type 1 p12(I) protein. J. Virol. 2001, 75, 6086-6094.

108. Mulloy, J.C.; Crowley, R.W.; Fullen, J.; Leonard, W.J.; Franchini, G. The human T-cell leukemia/lymphotropic virus type 1 p12(I) protein binds the interleukin-2 receptor beta and gamma (c) chains and effects their expression on the cell surface. J. Virol. 1996, 70, 3599-3605.

109. Nicot, C.; Mulloy, J.C.; Ferrari, M.G.; Johnson, J.M.; Fu, K.; Fukumoto, R.; Trovato, R.; Fullen, J.; Leonard, W.J.; Franchini, G. HTLV-1 p12(I) protein enhances STAT5 activation and decreases the interleukin-2 requirement for proliferation of primary human peripheral blood mononuclear cells. Blood 2001, 98, 823-829.

110. Taylor, J.M.; Brown, M.; Nejmeddine, M.; Kim, K.J.; Ratner, L.; Lairmore, M.; Nicot, C. Novel role for interleukin-2 receptor-Jak signaling in retrovirus transmission. J. Virol. 2009, 83, 11467-11476.

111. Fukumoto, R.; Andresen, V.; Bialuk, I.; Cecchinato, V.; Walser, J.C.; Valeri, V.W.; Nauroth, J.M.; Gessain, A.; Nicot, C.; Franchini, G. In vivo genetic mutations define predominant functions of the human T-cell leukemia/lymphoma virus p12I protein. Blood 2009, 113, 3726-3734.

112. Boxus, M.; Willems, L. Mechanisms of HTLV-1 persistence and transformation. Br. J. Cancer 2009, 101, 1497-1501.

113. Van Prooyen, N.; Andresen, V.; Gold, H.; Bialuk, I.; Pise-Masison, C.; Franchini, G. Hijacking the T-cell communication network by the human T-cell leukemia/lymphoma virus type 1 (HTLV-1) p12 and p8 proteins. Mol. Aspects Med. 2010, doi: 10.1016/j.mam.2010.07.001.

114. Kim, S.J.; Nair, A.M.; Fernandez, S.; Mathes, L.; Lairmore, M.D. Enhancement of LFA-1mediated $\mathrm{T}$ cell adhesion by human $\mathrm{T}$ lymphotropic virus type 1 p12I1. J. Immunol. 2006, 176, 5463-5470.

115. Robek, M.; Wong, F.; Ratner, L. Human T-cell leukemia virus type 1 pX-I and pX-II open reading frames are dispensable for the immortalization of primary lymphocytes. J. Virol. 1998, $72,4458-4462$.

116. Hiraragi, H.; Kim, S.J.; Phipps, A.J.; Silic-Benussi, M.; Ciminale, V.; Ratner, L.; Green, P.L.; Lairmore, M.D. Human T-lymphotropic virus type 1 mitochondrion-localizing protein p13(II) is required for viral infectivity in vivo. J. Virol. 2006, 80, 3469-3476.

117. Ciminale, V.; Zotti, L.; D'Agostino, D.M.; Ferro, T.; Casareto, L.; Franchini, G.; Bernardi, P.; Chieco-Bianchi, L. Mitochondrial targeting of the p13II protein coded by the X-II ORF of human T-cell leukemia/lymphotropic virus type I (HTLV-I). Oncogene 1999, 18, 4505-4514. 
118. Silic-Benussi, M.; Cavallari, I.; Zorzan, T.; Rossi, E.; Hiraragi, H.; Rosato, A.; Horie, K.; Saggioro, D.; Lairmore, M.D.; Willems, L.; Chieco-Bianchi, L.; D'Agostino, D.M.; Ciminale, V. Suppression of tumor growth and cell proliferation by p13II, a mitochondrial protein of human $\mathrm{T}$ cell leukemia virus type 1. Proc. Natl. Acad. Sci. U. S. A. 2004, 101, 6629-6634.

119. Hiraragi, H.; Michael, B.; Nair, A.; Silic-Benussi, M.; Ciminale, V.; Lairmore, M. Human Tlymphotropic virus type 1 mitochondrion-localizing protein p13II sensitizes Jurkat $\mathrm{T}$ cells to Rasmediated apoptosis. J. Virol. 2005, 79, 9449-9457.

120. Lefebvre, L.; Vanderplasschen, A.; Ciminale, V.; Heremans, H.; Dangoisse, O.; Jauniaux, J.C.; Toussaint, J.F.; Zelnik, V.; Burny, A.; Kettmann, R.; Willems, L. Oncoviral bovine leukemia virus G4 and human T-cell leukemia virus type $1 \mathrm{p} 13$ (II) accessory proteins interact with farnesyl pyrophosphate synthetase. J. Virol. 2002, 76, 1400-1414.

121. Saggioro, D.; Silic-Benussi, M.; Biasiotto, R.; D'Agostino, D.M.; Ciminale, V. Control of cell death pathways by HTLV-1 proteins. Front. Biosci. 2009, 14, 3338-3351.

122. Richardson, J.H.; Edwards, A.J.; Cruickshank, J.K.; Rudge, P.; Dalgleish, A.G. In vivo cellular tropism of human T-cell leukemia virus type 1. J. Virol. 1990, 64, 5682-5687.

123. Miyamoto, K.; Kamiya, T.; Minowada, J.; Tomita, N.; Kitajima, K. Transformation of CD8+ Tcells producing a strong cytopathic effect on CD4+ T-cells through syncytium formation by HTLV-II. Jpn. J. Cancer Res. 1991, 82, 1178-1183.

124. Wang, T.-G.; Ye, J.; Lairmore, M.; Green, P.L. In vitro cellular tropism of human T-cell leukemia virus type 2. AIDS Res. Hum. Retroviruses 2000, 16, 1661-1668.

125. Ye, J.; Xie, L.; Green, P.L. Tax and overlapping Rex sequences do not confer the distinct transformation tropisms of HTLV-1 and HTLV-2. J. Virol. 2003, 77, 7728-7735.

126. Newbound, G.C.; Andrews, J.M.; O'Rourke, J.P.; Brady, J.N.; Lairmore, M.D. Human T-cell lymphotropic virus type 1 Tax mediates enhanced transcription in CD4+ T-lymphocytes. J. Virol. 1996, 70, 2101-2106.

127. Nagai, M.; Brennan, M.B.; Sakai, J.A.; Mora, C.A.; Jacobson, S. CD8(+) T cells are an in vivo reservoir for human T-cell lymphotropic virus type I. Blood 2001, 98, 1858-1861.

128. Ijichi, S.; Ramundo, M.B.; Takahashi, H.; Hall, W.W. In vivo cellular tropism of human T-cell leukemia virus type II (HTLV-II). J. Exp. Med. 1992, 176, 293-296.

129. Lal, R.B.; Owen, S.M.; Rudolph, D.L.; Dawaon, C.; Prince, H. In Vivo Cellular Tropism of Human T-cell Lymphotrophic Virus Type-II is Not Restricted to CD8+ Cells. Virology 1995, 210, 441-447.

130. Xie, L.; Green, P.L. Envelope is a major viral determinant of the distinct in vitro cellular transformation tropism of human T-cell leukemia virus type 1 (HTLV-1) and HTLV-2. J. Virol. 2005, 79, 14536-14545.

131. Jones, K.S.; Fugo, K.; Petrow-Sadowski, C.; Huang, Y.; Bertolette, D.C.; Lisinski, I.; Cushman, S.W.; Jacobson, S.; Ruscetti, F.W. Human T-cell leukemia virus type 1 (HTLV-1) and HTLV-2 use different receptor complexes to enter T cells. J. Virol. 2006, 80, 8291-8302.

132. Takemoto, S.; Mulloy, J.C.; Cereseto, A.; Migone, T.S.; Patel, B.K.; Matsuoka, M.; Yamaguchi, K.; Takatsuki, K.; Kamihira, S.; White, J.D.; Leonard, W.J.; Waldmann, T.; Franchini, G. Proliferation of adult $\mathrm{T}$ cell leukemia/lymphoma cells is associated with the constitutive activation of JAK/STAT proteins. Proc. Natl. Acad. Sci. U. S. A. 1997, 94, 13897-13902. 
133. Franchini, G.; Mulloy, J.C.; Koralnik, I.J.; Lo, M.A.; Sparkowski, J.J.; Andresson, T.; Goldstein, D.J.; Schlegel, R. The human T-cell leukemia/lymphotropic virus type I p12I protein cooperates with the E5 oncoprotein of bovine papillomavirus in cell transformation and binds the 16kilodalton subunit of the vacuolar H+ ATPase. J. Virol. 1993, 67, 7701-7704.

134. Koralnik, I.J.; Mulloy, J.C.; Andresson, T.; Fullen, J.; Franchini, G. Mapping of the intermolecular association of human $\mathrm{T}$ cell leukaemia/lymphotropic virus type I p12I and the vacuolar H+-ATPase $16 \mathrm{kDa}$ subunit protein. J. Gen. Virol. 1995, 76 (Pt 8), 1909-1916.

135. Ding, W.; Albrecht, B.; Kelley, R.E.; Muthusamy, N.; Kim, S.J.; Altschuld, R.A.; Lairmore, M.D. Human T-cell lymphotropic virus type 1 p12(I) expression increases cytoplasmic calcium to enhance the activation of nuclear factor of activated T cells. J. Virol. 2002, 76, 10374-10382.

136. Albrecht, B.; D'Souza, C.D.; Ding, W.; Tridandapani, S.; Coggeshall, K.M.; Lairmore, M.D. Activation of nuclear factor of activated T cells by human T- lymphotropic virus type 1 accessory protein p12. J. Virol. 2002, 76, 3493-3501.

137. Kim, S.J.; Ding, W.; Albrecht, B.; Green, P.L.; Lairmore, M.D. A conserved calcineurin-binding motif in human $\mathrm{T}$ lymphotropic virus type $1 \mathrm{p} 12 \mathrm{I}$ functions to modulate nuclear factor of activated T cell activation. J. Biol. Chem. 2003, 278, 15550-15557.

138. Nair, A.; Michael, B.; Hiraragi, H.; Fernandez, S.; Feuer, G.; Boris-Lawrie, K.; Lairmore, M. Human T lymphotropic virus type 1 accessory protein p12I modulates calcium-mediated cellular gene expression and enhances p300 expression in T lymphocytes. AIDS Res. Hum. Retroviruses 2005, 21, 273-284.

139. Merl, S.; Kloster, B.; Moore, J.; Hubbell, C.; Tomar, R.; Davey, F.; Kalinowski, D.; Planas, A.; Ehrlich, G.; Clark, D.; Comis, R.; Poiesz, B. Efficient transformation of previously activated and dividing T lymphocytes by human T cell leukemia-lymphoma virus. Blood 1984, 64, 967-974.

140. Wucherpfennig, K.W.; Hollsberg, P.; Richardson, J.H.; Benjamin, D.; Hafler, D.A. T-cell activation by autologous human T-cell leukemia virus type I-infected T-cell clones. Proc. Natl. Acad. Sci. U. S. A. 1992, 89, 2110-2114.

141. Franchini, G. Molecular mechanisms of human T-cell leukemia/lymphotropic virus type 1 infection. Blood 1995, 86, 3619-3639.

142. Matsuoka, M.; Green, P.L. The HBZ gene, a key player in HTLV-1 pathogenesis. Retrovirology 2009, 6, 71 .

143. Migone, T.S.; Lin, J.X.; Cereseto, A.; Mulloy, J.C.; O'Shea, J.J.; Franchini, G.; Leonard, W.J. Constitutively activated Jak-STAT pathway in T cells transformed with HTLV-I. Science 1995, 269, 79-81.

144. Migone, T.S.; Cacalano, N.A.; Taylor, N.; Yi, T.; Waldmann, T.A.; Johnston, J.A. Recruitment of SH2-containing protein tyrosine phosphatase SHP-1 to the interleukin 2 receptor; loss of SHP-1 expression in human T-lymphotropic virus type I-transformed T cells. Proc. Natl. Acad. Sci. U. S. A. 1998, 95, 3845-3850.

145. Ressler, S.; Connor, L.M.; Marriott, S.J. Cellular transformation by human T-cell leukemia virus type I. FEMS Microbiol. Lett. 1996, 140, 99-109.

146. Fujii, M.; Niki, T.; Mori, T.; Matsuda, T.; Matsui, M.; Nomura, N.; Seiki, M. HTLV-1 Tax induces expression of various immediate early serum responsive genes. Oncogene 1991, 6, 2349-2352. 
147. Akagi, T.; Takeda, I.; Oka, T.; Ohtsuki, Y.; Yano, S.; Miyoshi, I. Experimental infection of rabbits with human T-cell leukemia virus type 1. Jpn. J. Can. Res. 1985, 76, 86-94.

148. Lairmore, M.D.; Roberts, B.; Frank, D.; Rovnak, J.; Weiser, M.G.; Cockerell, G.L. Comparative biological response of rabbits infected with human T-lymphotropic virus type I isolates from patients with lymphoproliferative and neurodegenerative disease. Int. J. Cancer 1992, 50, 124-130.

149. Ibrahim, F.; Fiette, L.; Gessain, A.; Buisson, N.; de-The, G.; Bomford, R. Infection of rats with human T-cell leukemia virus type-I: susceptibility of inbred strains, antibody response and provirus location. Int. J. Cancer 1994, 58, 446-451.

150. Suga, T.; Kameyama, T.; Kinoshita, T.; al, e. Infection of rats with HTLV-I: a small-animal model for HTLV-I carriers. Int. J. Cancer 1991, 49, 764-769.

151. Kataoka, R.; Takehara, N.; Iwahara, Y.; et al Transmission of HTLV-I by blood transfusion and its prevention by passive immunization in rabbits. Blood 1990, 76, 1657-1661.

152. Miyoshi, I.; Takehara, N.; Sawada, T.; et al Immunoglobulin prophylaxis against HTLV-I in a rabbit model. Leukemia 1992, 6, 24-26.

153. Sawada, T.; Iwahara, Y.; Ishii, K.; Taguchi, H.; Hoshino, H.; Miyoshi, I. Immunoglobulin prophylaxis against milkborne transmission of HTLV-I in rabbits. J. Infect. Dis. 1991, 164, 1193-1196.

154. Takehara, N.; Iwahara, Y.; Uemura, Y.; Sawada, T.; Ohtsuki, Y.; Iwai, H.; Hoshino, H.; Miyoshi, I. Effect of immunization on HTLV-1 infection in rabbits. Int. J. Cancer 1989, 44, 332-336.

155. Tanaka, Y.; Tanaka, R.; Terada, E.; Koyanagi, Y.; Miyano-Kurosaki, N.; Yamamoto, N.; Baba, E.; Nakamura, M.; Shida, H. Induction of antibody responses that neutralize human T-cell leukemia virus type I infection in vitro and in vivo by peptide immunization. J. Virol. 1994, 68, 6323-6331.

156. Ohashi, T.; Hanabuchi, S.; Kato, H.; Koya, Y.; Takemura, F.; Hirokawa, K.; Yoshiki, T.; Tanaka, Y.; Fujii, M.; Kannagi, M. Induction of adult T-cell leukemia-like lymphoproliferative disease and its inhibition by adoptive immunotherapy in T-cell-deficient nude rats inoculated with syngeneic human T-cell leukemia virus type 1-immortalized cells. J. Virol. 1999, 73, 6031-6040.

157. Murata, N.; Hakoda, E.; Machida, H.; Ikezoe, T.; Sawada, T.; Hoshino, H.; Miyoshi, I. Prevention of HTLV-1 infection in Japanese macaques by passive immunization. Leukemia 1996, 10, 1971-1974.

158. Nakamura, H.; Hayami, M.; Ohta, Y.; Moriyama, I.; Saito, S.; Sugamura, K.; Hinuma, Y. Protection of cynomolgus monkeys against infection by human T-cell leukemia virus type-I by immunization with viral env gene products produced in Escherichia coli. Int. J. Cancer 1987, 40, 403-407.

159. Dewan, M.Z.; Takamatsu, N.; Hidaka, T.; Hatakeyama, K.; Nakahata, S.; Fujisawa, J.; Katano, H.; Yamamoto, N.; Morishita, K. Critical role for TSLC1 expression in the growth and organ infiltration of adult T-cell leukemia cells in vivo. J. Virol. 2008, 82, 11958-11963. 
160. Dewan, M.Z.; Terashima, K.; Taruishi, M.; Hasegawa, H.; Ito, M.; Tanaka, Y.; Mori, N.; Sata, T.; Koyanagi, Y.; Maeda, M.; Kubuki, Y.; Okayama, A.; Fujii, M.; Yamamoto, N. Rapid tumor formation of human T-cell leukemia virus type 1-infected cell lines in novel NODSCID/gammac(null) mice: suppression by an inhibitor against NF-kappaB. J. Virol. 2003, 77, 5286-5294.

161. Feuer, G.; Zack, J.A.; Harrington Jr, W.J.; Valderama, R.; Rosenblatt, J.D.; Wachsman, W.; Baird, S.M.; Chen, I.S.Y. Establishment of human T-cell leukemia virus type I T-cell lymphomas in severe combined immunodeficient mice. Blood 1993, 82, 722-731.

162. Imada, K.; Takaori-Kondo, A.; Akagi, T.; Shimotohno, K.; Sugamura, K.; Hattori, T.; Yamabe, H.; Okuma, M.; Uchiyama, T. Tumorigenicity of human T-cell leukemia virus type I-infected cell lines in severe combined immunodeficient mice and characterization of the cells proliferating in vivo. Blood 1995, 86, 2350-2357.

163. Kawano, N.; Ishikawa, F.; Shimoda, K.; Yasukawa, M.; Nagafuji, K.; Miyamoto, T.; Baba, E.; Tanaka, T.; Yamasaki, S.; Gondo, H.; Otsuka, T.; Ohshima, K.; Shultz, L.D.; Akashi, K.; Harada, M. Efficient engraftment of primary adult T-cell leukemia cells in newborn NOD/SCID/beta2microglobulin(null) mice. Leukemia 2005, 19, 1384-1390.

164. Kondo, A.; Imada, K.; Hattori, T.; Yamabe, H.; Tanaka, T.; Miyasaka, M.; Okuma, M.; Uchiyama, T. A model of in vivo cell proliferation of adult T-cell leukemia. Blood 1993, 82, 2501-2509.

165. Liu, Y.; Dole, K.; Stanley, J.; Richard, V.; Rosol, T.J.; Ratner, L.; Lairmore, M.D.; Feuer, G. Engraftment and tumorigenesis of HTLV-1 transformed T cell lines in SCID/bg and NOD/SCID mice. Leuk. Res. 2002, 26, 561-567.

166. Miyazato, P.; Yasunaga, J.; Taniguchi, Y.; Koyanagi, Y.; Mitsuya, H.; Matsuoka, M. De novo human T-cell leukemia virus type 1 infection of human lymphocytes in NOD-SCID, common gamma-chain knockout mice. J. Virol. 2006, 80, 10683-10691.

167. Phillips, K.E.; Herring, B.; Wilson, L.A.; Rickford, M.S.; Zhang, M.; Goldman, C.K.; Tso, J.Y.; Waldmann, T.A. IL-2Ralpha-Directed monoclonal antibodies provide effective therapy in a murine model of adult T-cell leukemia by a mechanism other than blockade of IL-2/IL-2Ralpha interaction. Cancer Res. 2000, 60, 6977-6984.

168. Benvenisty, N.; Ornitz, D.M.; Bennett, G.L.; Sahagan, B.G.; Kuo, A.; Cardiff, R.D.; Leder, P. Brain tumours and lymphomas in transgenic mice that carry HTLV-I LTR/c-myc and Ig/tax genes. Oncogene 1992, 7, 2399-2405.

169. Bieberich, C.J.; King, C.M.; Tinkle, B.T.; Jay, G. A transgenic model of transactivation by the Tax protein of HTLV-I. Virology 1993, 196, 309-318.

170. Coscoy, L.; Gonzalez-Dunia, D.; Tangy, F.; Syan, S.; Brahic, M.; Ozden, S. Molecular mechanism of tumorigenesis in mice transgenic for the human $\mathrm{T}$ cell leukemia virus Tax gene. Virology 1998, 248, 332-341.

171. Hasegawa, H.; Sawa, H.; Lewis, M.J.; Orba, Y.; Sheehy, N.; Yamamoto, Y.; Ichinohe, T.; Tsunetsugu-Yokota, Y.; Katano, H.; Takahashi, H.; Matsuda, J.; Sata, T.; Kurata, T.; Nagashima, K.; Hall, W.W. Thymus-derived leukemia-lymphoma in mice transgenic for the Tax gene of human T-lymphotropic virus type I. Nat. Med. 2006, 12, 466-472. 
172. Furuta, Y.; Aizawa, S.; Suda, Y.; Ikawa, Y.; Kishimoto, H.; Asano, Y.; Tada, T.; Hikikoshi, A.; Yoshida, M.; Seiki, M. Thymic atrophy characteristic in transgenic mice that harbor $\mathrm{pX}$ genes of human T-cell leukemia virus type I. J. Virol. 1989, 63, 3185-3189.

173. Kwon, H.; Ogle, L.; Benitez, B.; Bohuslav, J.; Montano, M.; Felsher, D.W.; Greene, W.C. Lethal cutaneous disease in transgenic mice conditionally expressing type I human $\mathrm{T}$ cell leukemia virus Tax. J. Biol. Chem. 2005, 280, 35713-35722.

174. Ratner, L. Pathogenesis and treatment of human T-cell leukemia virus infection Immunol. Res. 2005, 32, 217-223.

175. Brady, J.; Jeang, K.T.; Durall, J.; Khoury, G. Identification of the p40x-responsive regulatory sequences within the human T-cell leukemia virus type I long terminal repeat. J. Virol. 1987, 61, $2175-2181$.

176. Jeang, K.-T.; Boros, I.; Brady, J.; Radonovich, M.; Khoury, G. Characterization of cellular factors that interact with the human T-cell leukemia virus type I p40x-responsive 21-base-pair sequence. J. Virol. 1988, 62, 4499-4509.

177. Giam, C.Z.; Xu, Y.L. HTLV-I Tax gene product activates transcription via preexisting cellular factors and cAMP responsive element. J. Biol. Chem. 1989, 264, 15236-15241.

178. Zhao, L.J.; Giam, C.Z. Human T-cell lymphotropic virus type I (HTLV-I) transcriptional activator, Tax, enhances CREB binding to HTLV-I 21-base-pair repeats by protein-protein interaction. Proc. Natl. Acad. Sci. U. S. A. 1992, 89, 7070-7074.

179. Low, K.G.; Chu, H.M.; Schwartz, P.M.; Daniels, G.M.; Melner, M.H.; Comb, M.J. Novel interactions between human T-cell leukemia virus type I Tax and activating transcription factor 3 at a cyclic AMP-responsive element. Mol. Cell. Biol. 1994, 14, 4958-4974.

180. Bantignies, F.; Rousset, R.; Desbois, C.; Jalinot, P. Genetic characterization of transactivation of the human T-cell leukemia virus type 1 promoter: Binding of Tax to Tax-responsive element 1 is mediated by the cyclic AMP-responsive members of the CREB/ATF family of transcription factors. Mol. Cell. Biol. 1996, 16, 2174-2182.

181. Reddy, T.R.; Tang, H.; Li, X.; Wong-Staal, F. Functional interaction of the HTLV-1 transactivator Tax with activating transcription factor-4 (ATF4). Oncogene 1997, 14, 2785-2792.

182. Franklin, A.A.; Kubik, M.F.; Uittenbogaard, M.N.; Brauweiler, A.; Utaisincharoen, P.; Matthews, M.H.; Dynan, W.S.; Hoeffler, J.P.; Nyborg, J.K. Transactivation by the human T-cell leukemia virus Tax protein is mediated through enhanced binding of activating transcription factor-2 (ATF2) ATF-2 response and cAMP element-binding protein (CREB). J. Biol. Chem. 1993, 268, 21225-21231.

183. Ku, S.C.; Lee, J.; Lau, J.; Gurumurthy, M.; Ng, R.; Lwa, S.H.; Lee, J.; Klase, Z.; Kashanchi, F.; Chao, S.H. XBP-1, a novel human T-lymphotropic virus type 1 (HTLV-1) tax binding protein, activates HTLV-1 basal and tax-activated transcription. J. Virol. 2008, 82, 4343-4353.

184. Boxus, M.; Twizere, J.C.; Legros, S.; Dewulf, J.F.; Kettmann, R.; Willems, L. The HTLV-1 Tax interactome. Retrovirology 2008, 5, 76.

185. Perini, G.; Wagner, S.; Green, M.R. Recognition of bZIP proteins by the human T-cell leukaemia virus transactivator Tax. Nature 1995, 376, 602-605.

186. Wagner, S.; Green, M.R. HTLV-I Tax protein stimulation of DNA binding of bZIP proteins by enhancing dimerization. Science 1993, 262, 395-399. 
187. Anderson, M.G.; Dynan, W.S. Quantitative studies of the effect of HTLV-1 Tax protein on CREB protein-DNA binding. Nucleic Acids Res. 1994, 22, 3194-3201.

188. Yin, M.J.; Gaynor, R.B. HTLV-1 21 bp repeat sequences facilitate stable association between Tax and CREB to increase CREB binding affinity. J. Mol. Biol. 1996, 264, 20-31.

189. Kimzey, A.L.; Dynan, W.S. Specific regions of contact between human T-cell leukemia virus type I Tax protein and DNA identified by photocross-linking. J. Biol. Chem. 1998, 273, 13768-13775.

190. Lundblad, J.R.; Kwok, R.P.; Laurance, M.E.; Huang, M.S.; Richards, J.P.; Brennan, R.G.; Goodman, R.H. The human T-cell leukemia virus-1 transcriptional activator Tax enhances cAMPresponsive element-binding protein (CREB) binding activity through interactions with the DNA minor groove. J. Biol. Chem. 1998, 273, 19251-19259.

191. Jin, D.Y.; Jeang, K.T. HTLV-I Tax self-association in optimal trans-activation function. Nucleic Acids Res. 1997, 25, 379-387.

192. Tie, F.; Adya, N.; Greene, W.C.; Giam, C.-Z. Interaction of the human T-lymphotropic virus type 1 Tax dimer with CREB and the viral 21-base-pair repeat. J. Virol. 1996, 70, 8368-8374.

193. Koga, H.; Ohshima, T.; Shimotohno, K. Enhanced activation of tax-dependent transcription of human T-cell leukemia virus type I (HTLV-I) long terminal repeat by TORC3. J. Biol. Chem. 2004, 279, 52978-52983.

194. Siu, Y.T.; Chin, K.T.; Siu, K.L.; Yee Wai Choy, E.; Jeang, K.T.; Jin, D.Y. TORC1 and TORC2 coactivators are required for tax activation of the human T-cell leukemia virus type 1 long terminal repeats. J. Virol. 2006, 80, 7052-7059.

195. Kibler, K.V.; Jeang, K.T. CREB/ATF-dependent repression of cyclin a by human T-cell leukemia virus type 1 Tax protein. J. Virol. 2001, 75, 2161-2173.

196. Nicot, C.; Opavsky, R.; Mahieux, R.; Johnson, J.M.; Brady, J.N.; Wolff, L.; Franchini, G. Tax oncoprotein trans-represses endogenous B-myb promoter activity in human T cells. AIDS Res. Hum. Retroviruses 2000, 16, 1629-1632.

197. Fujii, M.; Iwai, K.; Oie, M.; Fukushi, M.; Yamamoto, N.; Kannagi, M.; Mori, N. Activation of oncogenic transcription factor AP-1 in T cells infected with human T cell leukemia virus type 1. AIDS Res. Hum. Retroviruses 2000, 16, 1603-1606.

198. Matsumoto, K.; Shibata, H.; Fujisawa, J.-I.; Inoue, H.; Hakura, A.; Tsukahara, T.; Fujji, M. Human T-cell leukemia virus type 1 Tax protein transforms rat fibroblasts via two distinct pathways. J. Virol. 1997, 71, 4445-4451.

199. Fujii, M.; Tsuchiya, H.; Chuhjo, T.; Akizawa, T.; Seiki, M. Interaction of HTLV-1 Tax1 with p67SRF causes the aberrant induction of cellular immediate early genes through CArG boxes. Genes Dev. 1992, 6, 2006-2076.

200. Fujii, M.; Chuhjo, T.; Minamino, T.; Masaaki, N.; Miyamoto, K.; Seiki, M. Identification of the Tax interaction region of serum response factor that mediates the aberrant induction of immediate early genes through CArG boxes by HTLV-I Tax. Oncogene 1995, 11, 7-14.

201. Suzuki, T.; Hirai, H.; Fujisawa, J.; Fujita, T.; Yoshida, M. A transactivator Tax of human T-cell leukemia virus type 1 binds to NF- B p50 and serum response factor (SRF) and associates with enhancer DNAs of the NF B site and CArG box. Oncogene 1993, 8, 2391-2397. 
202. Dittmer, J.; Pise-Masison, C.A.; Clemens, K.E.; Choi, K.S.; Brady, J.N. Interaction of human Tcell lymphotropic virus type I Tax, Ets1, and Sp1 in transactivation of the PTHrP P2 promoter. J. Biol. Chem. 1997, 272, 4953-4958.

203. Shuh, M.; Derse, D. Ternary complex factors and cofactors are essential for human T-cell leukemia virus type 1 tax transactivation of the serum response element. J. Virol. 2000, 74, 11394-11397.

204. Siebenlist, U.; Franzoso, G.; Brown, K. Structure, regulation and function of NF-kappa B. Annu. Rev. Cell. Biol. 1994, 10, 405-455.

205. Perkins, N.D. Integrating cell-signalling pathways with NF-kappaB and IKK function. Nat. Rev. Mol. Cell. Biol. 2007, 8, 49-62.

206. Vallabhapurapu, S.; Karin, M. Regulation and function of NF-kappaB transcription factors in the immune system. Annu. Rev. Immunol. 2009, 27, 693-733.

207. Karin, M.; Ben-Neriah, Y. Phosphorylation meets ubiquitination: the control of NF-[kappa]B activity. Annu. Rev. Immunol. 2000, 18, 621-663.

208. Karin, M. Nuclear factor-kappaB in cancer development and progression. Nature 2006, 441, 431-436.

209. Higuchi, M.; Fujii, M. Distinct functions of HTLV-1 Tax1 from HTLV-2 Tax2 contribute key roles to viral pathogenesis. Retrovirology 2009, 6, 117.

210. Ballard, D.W.; Bohnlein, E.; Lowenthal, J.W.; Wano, Y.; Franza, B.R.; Greene, W.C. HTLV-I tax induces cellular proteins that activate the kappa B element in the IL-2 receptor alpha gene. Science 1988, 241, 1652-1655.

211. Ruben, S.; Poteat, H.; Tan, T.H.; Kawakami, K.; Roeder, R.; Haseltine, W.; Rosen, C.A. Cellular transcription factors and regulation of IL-2 receptor gene expression by HTLV-I tax gene product. Science 1988, 241, 89-92.

212. Arima, N.; Molitor, J.A.; Smith, M.R.; Kim, J.H.; Daitoku, Y.; Greene, W.C. Human T-cell leukemia virus type I Tax induces expression of the rel-related family of kappa B enhancerbinding proteins: Evidence for a pretranslational component of regulation. J. Virol. 1991, 65, 6892-6899.

213. Sun, S.C.; Yamaoka, S. Activation of NF-kappaB by HTLV-I and implications for cell transformation. Oncogene 2005, 24, 5952-5964.

214. Yamaoka, S.; Courtois, G.; Bessia, C.; Whiteside, S.T.; Weil, R.; Agou, F.; Kirk, H.E.; Kay, R.J.; Israel, A. Complementation cloning of NEMO, a component of the IkappaB kinase complex essential for NF-kappaB activation. Cell 1998, 93, 1231-1240.

215. Sun, S.C.; Ballard, D.W. Persistent activation of NF-kappaB by the tax transforming protein of HTLV-1: hijacking cellular IkappaB kinases. Oncogene 1999, 18, 6948-6958.

216. Wu, X.; Sun, S.C. Retroviral oncoprotein Tax deregulates NF-kappaB by activating Tak1 and mediating the physical association of Tak1-IKK. EMBO Rep. 2007, 8, 510-515.

217. Bex, F.; Murphy, K.; Wattiez, R.; Burny, A.; Gaynor, R.B. Phosphorylation of the human T-cell leukemia virus type 1 transactivator Tax on adjacent serine residues is critical for Tax activation. J. Virol. 1999, 73, 738-745. 
218. Peloponese, J.M., Jr.; Iha, H.; Yedavalli, V.R.; Miyazato, A.; Li, Y.; Haller, K.; Benkirane, M.; Jeang, K.T. Ubiquitination of human T-cell leukemia virus type 1 tax modulates its activity. J. Virol. 2004, 78, 11686-11695.

219. Lamsoul, I.; Lodewick, J.; Lebrun, S.; Brasseur, R.; Burny, A.; Gaynor, R.B.; Bex, F. Exclusive ubiquitination and sumoylation on overlapping lysine residues mediate NF-kappaB activation by the human T-cell leukemia virus tax oncoprotein. Mol. Cell. Biol. 2005, 25, 10391-10406.

220. Nasr, R.; Chiari, E.; El-Sabban, M.; Mahieux, R.; Kfoury, Y.; Abdulhay, M.; Yazbeck, V.; Hermine, O.; de The, H.; Pique, C.; Bazarbachi, A. Tax ubiquitylation and sumoylation control critical cytoplasmic and nuclear steps of NF-kappaB activation. Blood 2006, 107, 4021-4029.

221. Shembade, N.; Harhaj, N.S.; Yamamoto, M.; Akira, S.; Harhaj, E.W. The human T-cell leukemia virus type 1 Tax oncoprotein requires the ubiquitin-conjugating enzyme Ubc13 for NF-kappaB activation. J. Virol. 2007, 81, 13735-13742.

222. Gatza, M.L.; Dayaram, T.; Marriott, S.J. Ubiquitination of HTLV-I Tax in response to DNA damage regulates nuclear complex formation and nuclear export. Retrovirology 2007, 4, 95.

223. Lodewick, J.; Lamsoul, I.; Polania, A.; Lebrun, S.; Burny, A.; Ratner, L.; Bex, F. Acetylation of the human T-cell leukemia virus type 1 Tax oncoprotein by p300 promotes activation of the NF-kappaB pathway. Virology 2009, 386, 68-78.

224. Journo, C.; Filipe, J.; About, F.; Chevalier, S.A.; Afonso, P.V.; Brady, J.N.; Flynn, D.; Tangy, F.; Israel, A.; Vidalain, P.O.; Mahieux, R.; Weil, R. NRP/Optineurin Cooperates with TAX1BP1 to potentiate the activation of NF-kappaB by human T-lymphotropic virus type 1 tax protein. PLoS Pathog. 2009, 5, e1000521.

225. Xiao, G.; Cvijic, M.E.; Fong, A.; Harhaj, E.W.; Uhlik, M.T.; Waterfield, M.; Sun, S.C. Retroviral oncoprotein Tax induces processing of NF-kappaB2/p100 in T cells: evidence for the involvement of IKKalpha. EMBO J. 2001, 20, 6805-6815.

226. Higuchi, M.; Tsubata, C.; Kondo, R.; Yoshida, S.; Takahashi, M.; Oie, M.; Tanaka, Y.; Mahieux, R.; Matsuoka, M.; Fujii, M. Cooperation of NF-kappaB2/p100 activation and the PDZ domain binding motif signal in human T-cell leukemia virus type 1 (HTLV-1) Tax1 but not HTLV-2 Tax2 is crucial for interleukin-2-independent growth transformation of a T-cell line. J. Virol. 2007, 81, 11900-11907.

227. Lairmore, M.D.; Silverman, L.; Ratner, L. Animal models for human T-lymphotropic virus type 1 (HTLV-1) infection and transformation. Oncogene 2005, 24, 6005-6015.

228. Ballard, D.W.; Bohnlein, E.; Hoffman, J.A.; Bogerd, H.P.; Dixon, E.P.; Franza, B.R.; Greene, W.C. Activation of the interleukin-2 receptor alpha gene: regulatory role for DNA-protein interactions flanking the kappa B enhancer. New. Biol. 1989, 1, 83-92.

229. Ruben, S.M.; Perkins, A.; Rosen, C.A. Activation of NF-kappa B by the HTLV-I trans-activator protein Tax requires an additional factor present in lymphoid cells. New. Biol. 1989, 1, 275-284.

230. Chen, J.; Petrus, M.; Bryant, B.R.; Phuc Nguyen, V.; Stamer, M.; Goldman, C.K.; Bamford, R.; Morris, J.C.; Janik, J.E.; Waldmann, T.A. Induction of the IL-9 gene by HTLV-I Tax stimulates the spontaneous proliferation of primary adult T-cell leukemia cells by a paracrine mechanism. Blood 2008, 111, 5163-5172. 
231. Waldele, K.; Schneider, G.; Ruckes, T.; Grassmann, R. Interleukin-13 overexpression by tax transactivation: a potential autocrine stimulus in human T-cell leukemia virus-infected lymphocytes. J. Virol. 2004, 78, 6081-6090.

232. Silbermann, K.; Schneider, G.; Grassmann, R. Stimulation of interleukin-13 expression by human T-cell leukemia virus type 1 oncoprotein Tax via a dually active promoter element responsive to NF-kappaB and NFAT. J. Gen. Virol. 2008, 89, 2788-2798.

233. Azimi, N.; Brown, K.; Bamford, R.N.; Tagaya, Y.; Siebenlist, U.; Waldmann, T.A. Human T cell lymphotropic virus type I Tax protein trans-activates interleukin 15 gene transcription through an NF-kappaB site. Proc. Natl. Acad. Sci. U. S. A. 1998, 95, 2452-2457.

234. Mariner, J.M.; Lantz, V.; Waldmann, T.A.; Azimi, N. Human T cell lymphotropic virus type I Tax activates IL-15R alpha gene expression through an NF-kappa B site. J. Immunol. 2001, 166, 2602-2609.

235. Mizuguchi, M.; Asao, H.; Hara, T.; Higuchi, M.; Fujii, M.; Nakamura, M. Transcriptional activation of the interleukin-21 gene and its receptor gene by human T-cell leukemia virus type 1 Tax in human T-cells. J. Biol. Chem. 2009, 284, 25501-25511.

236. Mori, N.; Mukaida, N.; Ballard, D.W.; Matsushima, K.; Yamamoto, N. Human T-cell leukemia virus type I Tax transactivates human interleukin 8 gene through acting concurrently on AP-1 and nuclear factor-kappaB-like sites. Cancer Res. 1998, 58, 3993-4000.

237. Mori, N.; Ueda, A.; Ikeda, S.; Yamasaki, Y.; Yamada, Y.; Tomonaga, M.; Morikawa, S.; Geleziunas, R.; Yoshimura, T.; Yamamoto, N. Human T-cell leukemia virus type I tax activates transcription of the human monocyte chemoattractant protein-1 gene through two nuclear factorkappaB sites. Cancer Res. 2000, 60, 4939-4945.

238. Mori, N.; Krensky, A.M.; Ohshima, K.; Tomita, M.; Matsuda, T.; Ohta, T.; Yamada, Y.; Tomonaga, M.; Ikeda, S.; Yamamoto, N. Elevated expression of CCL5/RANTES in adult T-cell leukemia cells: possible transactivation of the CCL5 gene by human T-cell leukemia virus type I tax. Int. J. Cancer 2004, 111, 548-557.

239. Hieshima, K.; Nagakubo, D.; Nakayama, T.; Shirakawa, A.K.; Jin, Z.; Yoshie, O. Tax-inducible production of $\mathrm{CC}$ chemokine ligand 22 by human $\mathrm{T}$ cell leukemia virus type 1 (HTLV-1)-infected $\mathrm{T}$ cells promotes preferential transmission of HTLV-1 to CCR4-expressing CD4+ T cells. J. Immunol. 2008, 180, 931-939.

240. Nagakubo, D.; Jin, Z.; Hieshima, K.; Nakayama, T.; Shirakawa, A.K.; Tanaka, Y.; Hasegawa, H.; Hayashi, T.; Tsukasaki, K.; Yamada, Y.; Yoshie, O. Expression of CCR9 in HTLV-1+ T cells and ATL cells expressing Tax. Int. J. Cancer 2007, 120, 1591-1597.

241. Jin, Z.; Nagakubo, D.; Shirakawa, A.K.; Nakayama, T.; Shigeta, A.; Hieshima, K.; Yamada, Y.; Yoshie, O. CXCR7 is inducible by HTLV-1 Tax and promotes growth and survival of HTLV-1infected T cells. Int. J. Cancer 2009, 125, 2229-2235.

242. Harhaj, E.W.; Harhaj, N.S.; Grant, C.; Mostoller, K.; Alefantis, T.; Sun, S.C.; Wigdahl, B. Human T cell leukemia virus type I Tax activates CD40 gene expression via the NF-kappa B pathway. Virology 2005, 333, 145-158.

243. Higashimura, N.; Takasawa, N.; Tanaka, Y.; Nakamura, M.; Sugamura, K. Induction of OX40, a receptor of gp34, on $\mathrm{T}$ cells by trans-acting transcriptional activator, Tax, of human $\mathrm{T}$-cell leukemia virus type I. Jap. J. Cancer Res. 1996, 87, 227-231. 
244. Miura, S.; Ohtani, K.; Numata, N.; Niki, M.; Ohbo, K.; Ina, Y.; Gojobori, T.; Tanaka, Y.; Tozawa, H.; Nakamura, M.; et al. Molecular cloning and characterization of a novel glycoprotein, gp34, that is specifically induced by the human T-cell leukemia virus type I transactivator p40tax. Mol. Cell. Biol. 1991, 11, 1313-1325.

245. Pichler, K.; Kattan, T.; Gentzsch, J.; Kress, A.K.; Taylor, G.P.; Bangham, C.R.; Grassmann, R. Strong induction of 4-1BB, a growth and survival promoting costimulatory receptor, in HTLV-1infected cultured and patients' T cells by the viral Tax oncoprotein. Blood 2008, 111, 4741-4751.

246. Ohtani, K.; Iwanaga, R.; Arai, M.; Huang, Y.; Matsumura, Y.; Nakamura, M. Cell type-specific E2F activation and cell cycle progression induced by the oncogene product Tax of human T-cell leukemia virus type I. J. Biol. Chem. 2000, 275, 11154-11163.

247. Iwanaga, R.; Ozono, E.; Fujisawa, J.; Ikeda, M.A.; Okamura, N.; Huang, Y.; Ohtani, K. Activation of the cyclin D2 and cdk6 genes through NF-kappaB is critical for cell-cycle progression induced by HTLV-I Tax. Oncogene 2008, 27, 5635-5642.

248. Haller, K.; Ruckes, T.; Schmitt, I.; Saul, D.; Derow, E.; Grassmann, R. Tax-dependent stimulation of G1 phase-specific cyclin-dependent kinases and increased expression of signal transduction genes characterize HTLV type 1-transformed T cells. AIDS Res. Hum. Retroviruses 2000, 16, $1683-1688$.

249. Haller, K.; Wu, Y.; Derow, E.; Schmitt, I.; Jeang, K.T.; Grassmann, R. Physical interaction of human T-cell leukemia virus type 1 tax with cyclin-dependent kinase 4 stimulates the phosphorylation of retinoblastoma protein. Mol. Cell. Biol. 2002, 22, 3327-3338.

250. Li, J.; Li, H.; Tsai, M.D. Direct binding of the N-terminus of HTLV-1 tax oncoprotein to cyclindependent kinase 4 is a dominant path to stimulate the kinase activity. Biochemistry 2003, 42, 6921-6928.

251. Fraedrich, K.; Muller, B.; Grassmann, R. The HTLV-1 Tax protein binding domain of cyclindependent kinase 4 (CDK4) includes the regulatory PSTAIRE helix. Retrovirology 2005, 2, 54.

252. Suzuki, T.; Kitao, S.; Matsushime, H.; Yoshida, M. HTLV-1 Tax protein interacts with cyclindependent kinase inhibitor p16INK4A and counteracts its inhibitory activity towards CDK4. EMBO J. 1996, 15, 1607-1614.

253. Suzuki, T.; Narita, T.; Uchida-Toita, M.; Yoshida, M. Down-regulation of the INK4 family of cyclin-dependent kinase inhibitors by tax protein of HTLV-1 through two distinct mechanisms. Virology 1999, 259, 384-391.

254. Low, K.G.; Dorner, L.F.; Fernando, D.B.; Grossman, J.; Jeang, K.T.; Comb, M.J. Human T-cell leukemia virus type I Tax releases cell cycle arrest induced by p16INK4a. J. Virol. 1997, 71, 1956-1962.

255. Watanabe, M.; Nakahata, S.; Hamasaki, M.; Saito, Y.; Kawano, Y.; Hidaka, T.; Yamashita, K.; Umeki, K.; Taki, T.; Taniwaki, M.; Okayama, A.; Morishita, K. Down-regulation of CDKN1A in adult $\mathrm{T}$ cell leukemia/lymphoma despite overexpression of CDKN1A in HTLV-1-infected cell lines. J. Virol. 2010, 84, 6966-6977

256. Peloponese, J.M., Jr.; Jeang, K.T. Role for Akt/protein kinase B and activator protein-1 in cellular proliferation induced by the human T-cell leukemia virus type 1 tax oncoprotein. J. Biol. Chem. 2006, 281, 8927-8938. 
257. Fukuda, R.I.; Tsuchiya, K.; Suzuki, K.; Itoh, K.; Fujita, J.; Utsunomiya, A.; Tsuji, T. Human Tcell leukemia virus type I tax down-regulates the expression of phosphatidylinositol 3,4,5trisphosphate inositol phosphatases via the NF-kappaB pathway. J. Biol. Chem. 2009, 284, 2680-2689.

258. Jeong, S.J.; Dasgupta, A.; Jung, K.J.; Um, J.H.; Burke, A.; Park, H.U.; Brady, J.N. PI3K/AKT inhibition induces caspase-dependent apoptosis in HTLV-1-transformed cells. Virology 2008, 370, 264-272.

259. Tomita, M.; Kikuchi, A.; Akiyama, T.; Tanaka, Y.; Mori, N. Human T-cell leukemia virus type 1 tax dysregulates beta-catenin signaling. J. Virol. 2006, 80, 10497-10505.

260. Shaw, R.J.; Cantley, L.C. Ras, PI(3)K and mTOR signalling controls tumour cell growth. Nature 2006, 441, 424-430.

261. Tomita, M.; Semenza, G.L.; Michiels, C.; Matsuda, T.; Uchihara, J.N.; Okudaira, T.; Tanaka, Y.; Taira, N.; Ohshiro, K.; Mori, N. Activation of hypoxia-inducible factor 1 in human T-cell leukaemia virus type 1 -infected cell lines and primary adult T-cell leukaemia cells. Biochem. J. 2007, 406, 317-323.

262. Tsukahara, T.; Kannagi, M.; Ohashi, T.; Kato, H.; Arai, M.; Nunez, G.; Iwanaga, Y.; Yamamoto, N.; Ohtani, K.; Nakamura, M.; Fujii, M. Induction of Bcl-x(L) expression by human T-cell leukemia virus type 1 Tax through NF-kappaB in apoptosis-resistant T-cell transfectants with Tax. J. Virol. 1999, 73, 7981-7987.

263. Kawakami, H.; Tomita, M.; Matsuda, T.; Ohta, T.; Tanaka, Y.; Fujii, M.; Hatano, M.; Tokuhisa, T.; Mori, N. Transcriptional activation of survivin through the NF-kappaB pathway by human Tcell leukemia virus type I tax. Int. J. Cancer 2005, 115, 967-974.

264. Okamoto, K.; Fujisawa, J.; Reth, M.; Yonehara, S. Human T-cell leukemia virus type-I oncoprotein Tax inhibits Fas-mediated apoptosis by inducing cellular FLIP through activation of NF-kappaB. Genes Cells 2006, 11, 177-191.

265. Krueger, A.; Fas, S.C.; Giaisi, M.; Bleumink, M.; Merling, A.; Stumpf, C.; Baumann, S.; Holtkotte, D.; Bosch, V.; Krammer, P.H.; Li-Weber, M. HTLV-1 Tax protects against CD95mediated apoptosis by induction of the cellular FLICE-inhibitory protein (c-FLIP). Blood 2006, 107, 3933-3939.

266. Bernal-Mizrachi, L.; Lovly, C.M.; Ratner, L. The role of NF-\{kappa $\}$ B-1 and NF-\{kappa $\}$ B-2mediated resistance to apoptosis in lymphomas. Proc. Natl. Acad. Sci. U. S. A. 2006, 103, 9220-9225.

267. Waldele, K.; Silbermann, K.; Schneider, G.; Ruckes, T.; Cullen, B.R.; Grassmann, R. Requirement of the human T-cell leukemia virus (HTLV-1) tax-stimulated HIAP-1 gene for the survival of transformed lymphocytes. Blood 2006, 107, 4491-4499.

268. Marriott, S.J.; Semmes, O.J. Impact of HTLV-I Tax on cell cycle progression and the cellular DNA damage repair response. Oncogene 2005, 24, 5986-5995.

269. Matsuoka, M.; Jeang, K.T. Human T-cell leukaemia virus type 1 (HTLV-1) infectivity and cellular transformation. Nat. Rev. Cancer 2007, 7, 270-280.

270. Chandhasin, C.; Ducu, R.I.; Berkovich, E.; Kastan, M.B.; Marriott, S.J. Human T-cell leukemia virus type 1 tax attenuates the ATM-mediated cellular DNA damage response. J. Virol. 2008, 82, 6952-6961. 
271. Durkin, S.S.; Guo, X.; Fryrear, K.A.; Mihaylova, V.T.; Gupta, S.K.; Belgnaoui, S.M.; Haoudi, A.; Kupfer, G.M.; Semmes, O.J. HTLV-1 Tax oncoprotein subverts the cellular DNA damage response via binding to DNA-dependent protein kinase. J. Biol. Chem. 2008, 283, 36311-36320.

272. Zhang, L.; Zhi, H.; Liu, M.; Kuo, Y.L.; Giam, C.Z. Induction of p21(CIP1/WAF1) expression by human T-lymphotropic virus type 1 Tax requires transcriptional activation and mRNA stabilization. Retrovirology 2009, 6, 35.

273. Hall, W.W.; Ishak, R.; Zhu, S.W.; Novoa, P.; Eiraku, N.; Takahashi, H.; Ferreira Mda, C.; Azevedo, V.; Ishak, M.O.; Ferreira Oda, C.; Monken, C.; Kurata, T. Human T lymphotropic virus type II (HTLV-II): epidemiology, molecular properties, and clinical features of infection. J. Acquir. Immune Defic. Syndr. Hum. Retrovirol. 1996, 13, S204-214.

274. Mahieux, R.; Pise-Masison, C.A.; Lambert, P.F.; Nicot, C.; De Marchis, L.; Gessain, A.; Green, P.; Hall, W.; Brady, J.N. Differences in the ability of human T-cell lymphotropic virus type 1 (HTLV-1) and HTLV-2 tax to inhibit p53 function. J. Virol. 2000, 74, 6866-6874.

275. Ariumi, Y.; Kaida, A.; Lin, J.Y.; Hirota, M.; Masui, O.; Yamaoka, S.; Taya, Y.; Shimotohno, K. HTLV-1 tax oncoprotein represses the p53-mediated trans-activation function through coactivator CBP sequestration. Oncogene 2000, 19, 1491-1499.

276. Gatza, M.L.; Watt, J.C.; Marriott, S. Cellular transformation by the HTLV-I Tax protein, a jackof-all-trades. Oncogene 2003, 22, 5141-5149.

277. Xie, L.; Yamamoto, B.; Haoudi, A.; Semmes, O.J.; Green, P.L. PDZ binding motif of HTLV-1 Tax promotes virus-mediated T-cell proliferation in vitro and persistence in vivo. Blood 2006, 107, 1980-1988.

278. Suzuki, T.; Ohsugi, Y.; Uchida-Toita, M.; Akiyama, T.; Yoshida, M. Tax oncoprotein of HTLV-1 binds to the human homologue of Drosophila discs large tumor suppressor protein, hDLG, and perturbs its function in cell growth control. Oncogene 1999, 18, 5967-5972.

279. Lee, S.S.; Weiss, R.S.; Javier, R.T. Binding of human virus oncoproteins to $\mathrm{hDlg} / \mathrm{SAP} 97$, a mammalian homolog of the Drosophila discs large tumor suppressor protein. Proc. Natl. Acad. Sci. U. S. A. 1997, 94, 6670-6675.

280. Wilson, K.C.; Center, D.M.; Cruikshank, W.W.; Zhang, Y. Binding of HTLV-1 tax oncoprotein to the precursor of interleukin-16, a T cell PDZ domain-containing protein. Virology 2003, 306, 60-67.

281. Ohashi, M.; Sakurai, M.; Higuchi, M.; Mori, N.; Fukushi, M.; Oie, M.; Coffey, R.J.; Yoshiura, K.; Tanaka, Y.; Uchiyama, M.; Hatanaka, M.; Fujii, M. Human T-cell leukemia virus type 1 Tax oncoprotein induces and interacts with a multi-PDZ domain protein, MAGI-3. Virology 2004, 320, 52-62.

282. Ishidate, T.; Matsumine, A.; Toyoshima, K.; Akiyama, T. The APC-hDLG complex negatively regulates cell cycle progression from the G0/G1 to S phase. Oncogene 2000, 19, 365-372.

283. Wu, Y.; Dowbenko, D.; Spencer, S.; Laura, R.; Lee, J.; Gu, Q.; Lasky, L.A. Interaction of the tumor suppressor PTEN/MMAC with a PDZ domain of MAGI3, a novel membrane-associated guanylate kinase. J. Biol. Chem. 2000, 275, 21477-21485.

284. Majone, F.; Semmes, O.J.; Jeang, K.-T. Induction of micronuclei by HTLV-I Tax: A cellular assay for function. Virology 1993, 193, 456-459. 
285. Semmes, O.J.; Majone, F.; Cantemir, C.; Turchetto, L.; Hjelle, B.; Jeang, K.T. HTLV-I and HTLV-II Tax: Differences in induction of micronuclei in cells and transcriptional activation of viral LTRs. Virology 1996, 217, 373-379.

286. Javier, R.T. Cell polarity proteins: common targets for tumorigenic human viruses. Oncogene 2008, 27, 7031-7046.

287. Aoyagi, T.; Takahashi, M.; Higuchi, M.; Oie, M.; Tanaka, Y.; Kiyono, T.; Aoyagi, Y.; Fujii, M. The PDZ domain binding motif (PBM) of human T-cell leukemia virus type 1 Tax can be substituted by heterologous PBMs from viral oncoproteins during T-cell transformation. Virus Genes 2008, 40, 193-199.

288. Larocca, D.; Chao, L.A.; Seto, M.H.; Brunck, T.K. Human T-cell leukemia virus minus strand transcription in infected cells. Biochem. Biophys. Res. Commun. 1989, 163, 1006-1013.

289. Yoshida, M.; Satou, Y.; Yasunaga, J.; Fujisawa, J.; Matsuoka, M. Transcriptional control of spliced and unspliced human T-cell leukemia virus type 1 bZIP factor (HBZ) gene. J. Virol. 2008, 82, 9359-9368.

290. Cavanagh, M.-H.; Landry, S.; Audet, B.; Arpin-Andre, C.; Hivin, P.; Pare, M.-E.; Thete, J.; Wattel, E.; Marriott, S.; Mesnard, J.-M.; Barbeau, B. HTLV-I antisense transcripts initiating in the 3' LTR are alternatively spliced and polyadenylated. Retrovirology 2006, 3, 15.

291. Murata, K.; Hayashibara, T.; Sugahara, K.; Uemura, A.; Yamaguchi, T.; Harasawa, H.; Hasegawa, H.; Tsuruda, K.; Okazaki, T.; Koji, T.; Miyanishi, T.; Yamada, Y.; Kamihira, S. A novel alternative splicing isoform of human T-cell leukemia virus type $1 \mathrm{bZIP}$ factor (HBZ-SI) targets distinct subnuclear localization. J. Virol. 2006, 80, 2495-2505.

292. Landry, S.; Halin, M.; Vargas, A.; Lemasson, I.; Mesnard, J.M.; Barbeau, B. Upregulation of human T-cell leukemia virus type 1 antisense transcription by the viral tax protein. J. Virol. 2009, 83, 2048-2054.

293. Saito, M.; Matsuzaki, T.; Satou, Y.; Yasunaga, J.; Saito, K.; Arimura, K.; Matsuoka, M.; Ohara, Y. In vivo expression of the HBZ gene of HTLV-1 correlates with proviral load, inflammatory markers and disease severity in HTLV-1 associated myelopathy/tropical spastic paraparesis (HAM/TSP). Retrovirology 2009, 6, 19.

294. Usui, T.; Yanagihara, K.; Tsukasaki, K.; Murata, K.; Hasegawa, H.; Yamada, Y.; Kamihira, S. Characteristic expression of HTLV-1 basic zipper factor (HBZ) transcripts in HTLV-1 proviruspositive cells. Retrovirology 2008, 5, 34 .

295. Hivin, P.; Frederic, M.; Arpin-Andre, C.; Basbous, J.; Gay, B.; Thebault, S.; Mesnard, J.M. Nuclear localization of HTLV-I bZIP factor (HBZ) is mediated by three distinct motifs. J. Cell. Sci. 2005, 118, 1355-1362.

296. Kuhlmann, A.S.; Villaudy, J.; Gazzolo, L.; Castellazzi, M.; Mesnard, J.M.; Duc Dodon, M. HTLV-1 HBZ cooperates with JunD to enhance transcription of the human telomerase reverse transcriptase gene (hTERT). Retrovirology 2007, 4, 92.

297. Zhao, T.; Yasunaga, J.; Satou, Y.; Nakao, M.; Takahashi, M.; Fujii, M.; Matsuoka, M. Human Tcell leukemia virus type $1 \mathrm{bZIP}$ factor selectively suppresses the classical pathway of NF-kappaB. Blood 2009, 113, 2755-2764. 
298. Isono, O.; Ohshima, T.; Saeki, Y.; Matsumoto, J.; Hijikata, M.; Tanaka, K.; Shimotohno, K. Human T-cell leukemia virus type $1 \mathrm{HBZ}$ protein bypasses the targeting function of ubiquitination. J. Biol. Chem. 2008, 283, 34273-34282.

299. Arnold, J.; Yamamoto, B.; Li, M.; Phipps, A.J.; Younis, I.; Lairmore, M.D.; Green, P.L. Enhancement of infectivity and persistence in vivo by HBZ, a natural antisense coded protein of HTLV-1. Blood 2006, 107, 3976-3982.

300. Hivin, P.; Basbous, J.; Raymond, F.; Henaff, D.; Arpin-Andre, C.; Robert-Hebmann, V.; Barbeau, B.; Mesnard, J.M. The HBZ-SP1 isoform of human T-cell leukemia virus type I represses JunB activity by sequestration into nuclear bodies. Retrovirology 2007, 4, 14.

301. Matsumoto, J.; Ohshima, T.; Isono, O.; Shimotohno, K. HTLV-1 HBZ suppresses AP-1 activity by impairing both the DNA-binding ability and the stability of c-Jun protein. Oncogene 2005, 24, 1001-1010.

302. Barbeau, B.; Mesnard, J.M. Does the HBZ gene represent a new potential target for the treatment of adult T-cell leukemia? Int. Rev. Immunol. 2007, 26, 283-304.

303. Ohshima, T.; Mukai, R.; Nakahara, N.; Matsumoto, J.; Isono, O.; Kobayashi, Y.; Takahashi, S.; Shimotohno, K. HTLV-1 basic leucine-zipper factor, HBZ, interacts with MafB and suppresses transcription through a Maf recognition element. J. Cell. Biochem. 2010, 111,187-194.

304. Mesnard, J.M.; Barbeau, B.; Devaux, C. HBZ, a new important player in the mystery of adult T-cell leukemia. Blood 2006, 108, 3979-3982.

305. Suemori, K.; Fujiwara, H.; Ochi, T.; Ogawa, T.; Matsuoka, M.; Matsumoto, T.; Mesnard, J.M.; Yasukawa, M. HBZ is an immunogenic protein, but not a target antigen for human T-cell leukemia virus type 1-specific cytotoxic T lymphocytes. J. Gen. Virol. 2009, 90, 1806-1811.

306. Li, M.; Green, P.L. Detection and quantitation of HTLV-1 and HTLV-2 mRNA species by realtime RT-PCR. J. Virol. Methods 2007, 142, 159-168.

307. Li, M.; Kesic, M.; Yin, H.; Lianbo, Y.; Green, P. Kinetic analysis of Human T-cell leukemia virus type 1 gene expression in cell culture and infected animals. J. Virol. 2009, 83, 3788-3797.

308. Morrison, T.E.; Kenney, S.C. BZLF1, an Epstein-Barr virus immediate-early protein, induces p65 nuclear translocation while inhibiting p65 transcriptional function. Virology 2004, 328, 219-232.

309. Polakowski, N.; Gregory, H.; Mesnard, J.M.; Lemasson, I. Expression of a protein involved in bone resorption, Dkk1, is activated by HTLV-1 bZIP factor through its activation domain. Retrovirology 2010, 7, 61.

310. Yoshida, M. Multiple viral strategies of HTLV-1 for dysregulation of cell growth control. Annu. Rev. Immunol. 2001, 19, 475-496.

311. Takeda, S.; Maeda, M.; Morikawa, S.; Taniguchi, Y.; Yasunaga, J.; Nosaka, K.; Tanaka, Y.; Matsuoka, M. Genetic and epigenetic inactivation of tax gene in adult T-cell leukemia cells. Int. J. Cancer 2004, 109, 559-567.

312. Koiwa, T.; Hamano-Usami, A.; Ishida, T.; Okayama, A.; Yamaguchi, K.; Kamihira, S.; Watanabe, T. 5'-long terminal repeat-selective CpG methylation of latent human T-cell leukemia virus type 1 provirus in vitro and in vivo. J. Virol. 2002, 76, 9389-9397.

313. Taniguchi, Y.; Nosaka, K.; Yasunaga, J.; Maeda, M.; Mueller, N.; Okayama, A.; Matsuoka, M. Silencing of human T-cell leukemia virus type I gene transcription by epigenetic mechanisms. Retrovirology 2005, 2, 64. 
314. Tamiya, S.; Matsuoka, M.; Etoh, K.; Watanabe, T.; Kamihira, S.; Yamaguchi, K.; Takatsuki, K. Two types of defective human T-lymphotropic virus type I provirus in adult T-cell leukemia. Blood 1996, 88, 3065-3073.

315. Furukawa, Y.; Kubota, R.; Tara, M.; Izumo, S.; Osame, M. Existence of escape mutant in HTLV-I tax during the development of adult T-cell leukemia. Blood 2001, 97, 987-993.

316. Miyazaki, M.; Yasunaga, J.; Taniguchi, Y.; Tamiya, S.; Nakahata, T.; Matsuoka, M. Preferential selection of human T-cell leukemia virus type 1 provirus lacking the 5 ' long terminal repeat during oncogenesis. J. Virol. 2007, 81, 5714-5723.

317. Sinha-Datta, U.; Datta, A.; Ghorbel, S.; Dodon, M.D.; Nicot, C. Human T-cell Lymphotrophic Virus Type I Rex and p30 Interactions Govern the Switch between Virus Latency and Replication. J. Biol. Chem. 2007, 282, 14608-14615.

318. Fan, J.; Ma, G.; Nosaka, K.; Tanabe, J.; Satou, Y.; Koito, A.; Wain-Hobson, S.; Vartanian, J.P.; Matsuoka, M. APOBEC3G Generates Nonsense Mutations in HTLV-1 Proviral Genomes In Vivo. J. Virol. 2010, 84, 7278-7287.

(C) 2010 by the authors; licensee MDPI, Basel, Switzerland. This article is an open access article distributed under the terms and conditions of the Creative Commons Attribution license (http://creativecommons.org/licenses/by/3.0/). 